\title{
1 Intestinal microbiota of whitefish (Coregonus sp.) species 2 pairs and their hybrids in natural and controlled 3 environment.
}

4 Authors: Maelle Sevellec ${ }^{1}$, Martin Laporte ${ }^{1}$, Alex Bernatchez ${ }^{1}$, Nicolas Derome ${ }^{1}$, and 5 Louis Bernatchez ${ }^{1}$.

6 1. Institut de Biologie Intégrative et des Systèmes (IBIS), Pavillon Charles-Eugène-

7 Marchand, 1030, Avenue de la Médecine, Université Laval, Québec (Québec) G1V 0A6, $8 \quad$ Canada. 


\section{Abstract}

10 It is becoming increasingly clear that wild animals have never existed without symbiotic

11 interactions with microbiota. Therefore, investigating relationships between microbiota and their

12 host is essential towards a full understanding of how animal evolve and adapt to their

13 environment. The Lake Whitefish (Coregonus clupeaformis) is a well-documented model for the

14 study of ecological speciation, where the dwarf species (limnetic niche specialist) evolved

15 independently and repeatedly from the normal species (benthic niche specialist). In this study, we

16 compared the transient intestinal microbiota among five wild sympatric species pairs of whitefish

17 as well as captive representatives of dwarf and normal species and their reciprocal hybrids reared

18 in identical controlled conditions. We sequenced the 16s rRNA gene V3-V4 regions of the

19 transient intestinal microbiota present in a total of 185 whitefish to (i) test for parallelism in the

20 transient intestinal microbiota among sympatric pairs of whitefish, (ii) test for transient intestinal

21 microbiota differences among dwarf, normal and both hybrids reared under identical conditions

22 and (iii) compare intestinal microbiota between wild and captive whitefish. A significant effect of

23 host species on microbiota taxonomic composition was observed in the wild when all lakes where

24 analyzed together, and species effect was observed in three of the five species pairs. In captive

25 whitefish, an influence of host (normal, dwarf and hybrids) was also detected on microbiota

26 taxonomic composition and tens of genera specific to dwarf, normal or hybrids were highlighted.

27 Hybrid microbiota was not intermediate; instead its composition fell outside of that observed in

28 the parental forms and this was observed in both reciprocal hybrid crosses. Interestingly, six

29 genera formed a bacterial core which was present in captive and wild whitefish, suggesting a

30 horizontal microbiota transmission. Although diet appeared to be a major driving force for

31 microbiota evolution, our results suggested a more complex interaction among the host, the

32 microbiota and the environment leading to three distinct evolutionary paths of the intestinal

33 microbiota. 


\section{Introduction}

Woese and Wheelis (1998) referred the Earth as a microbial planet, where macro-

organisms are recent additions. Similar biochemical reactions between eukaryotes and

37 prokaryotes in addition to the endosymbiotic theory suggest that eukaryotes evolved from

38 prokaryotes $[1,2]$. In addition, eukaryote-prokaryote cooperation fundamental to assemble more

39 complex structures as multicellular organisms [3]. Hence, animals and plants have never been

40 autonomous entities as they have always co-evolved in closed association with microbes [4].

41 Recent studies highlighted the substantial impact of microbiota on their host, for instance by

42 causing the differential expression of hundreds of genes between germ-free and conventional

43 organisms in several species $[5,6]$. Furthermore, it is now clear that part of the microbiota is

44 transmitted across generations in many animals and plants by various means [7]. In fishes in

45 particular, the mother allocates antimicrobial compounds to the eggs before spawning $[8,9]$. This

46 maternal selection of bacteria influences the first bacteria that will be in contact with the sterile

47 larvae during hatching [10]. Clearly then, a holistic understanding of macro-organisms

48 biodiversity requires the investigation of their association with microbiota and their co-evolution.

49 The hologenome concept stipulates that the genome of the host and the microbiome (i.e.

50 sum of the genetic information of the microbiota) act in consortium as a unique biological entity,

51 that is, the holobiont [11]. Besides playing a role in their host adaptation to their environments

52 [12], the microbiota may also be involved in reproductive isolation, either in the form of a pre-

53 zygotic barrier by influencing the host's mate choice by chemosensory signals $[13,14,15]$ or

54 post-zygotic barrier by producing genome and microbiome incompatibilities in hybrids, in

55 accordance to the Bateson, Dobzhansky and Muller model of genetic incompatibilities [13, 16,

56 17]. Because the bacterial community of the gastrointestinal tract is implicated in many critical

57 functions essential for development and immune responses, such as fermentation, synthesis and 
58 degradation functions, the intestinal microbiota could play an important role on its host's adaptive

59 potential $[11,12,18]$.

60 Fishes as a group comprise the greatest taxonomic diversity of vertebrates and a major food

61 resource for human populations [19, 20], yet little is known about the relationship with their

62 microbiota and its evolution. A better understanding of fish intestinal microbiota is thus necessary

63 towards filling the knowledge gap relative to the already well characterized mammals and insect

64 microbiota [21]. The Lake Whitefish (Coregonus clupeaformis) is a well-studied system that

65 represents a continuum in the early stage of speciation where sympatric species pairs of dwarf

66 and normal species evolved independently in several lakes in northeastern North America [22,

67 23]. The normal species is specialized for using the trophic benthic niche, feeding on diverse prey

68 as zoobenthos and molluscs. It is characterized by rapid growth, late sexual maturity and a long

69 lifespan $[24,25]$. In contrast, the dwarf whitefish is a limnetic specialist which feeds almost

70 exclusively on zooplankton and is characterized by slower growth, early sexual maturation and

71 shorter lifespan compared to the normal species. Previous transcriptomic studies revealed over-

72 expression of genes implicated with survival functions (e.g. enhanced swimming performance for

73 predator avoidance, detoxification) in dwarf whitefish, whereas normal whitefish show over-

74 expression of genes associated with growth functions [22, 26]. Moreover, many other

75 physiological, morphological and behavioral traits display parallel differences among these two

76 whitefish species that correspond to their respective trophic specialization [22, 27-33]. Thus, the

77 recent speciation and the clear trophic segregation make the whitefish species pairs an excellent

78 model to study the role of intestinal microbiota in the context of ecological speciation. Two

79 previous studies documented the variation of two microbial niches in Lake Whitefish species

80 pairs, the kidney and the intestinal adherent communities [34, 35]. Although parallel pattern was

81 highlighted between normal and dwarf species in the kidney communities, no clear evidence for

82 parallelism was observed in the adherent intestinal microbiota. However, the water bacterial 
83 community was distinct from the adherent intestinal microbiota, indicating an intrinsic properties

84 of the host microbiota [35].

85 Interestingly, there are emerging evidences that ingested environmental bacteria, including

86 prey microbiota, play a significant role on the overall gut microbiota, either by stimulating

87 colonization resistance or by providing additional functions to the host [36]. This allochthonous

88 microbial community is called the transient microbiota. However, few studies tested parallelism

89 patterns in fish intestinal microbiota [34, 37-41]. Also, the effect of the hybridization of two

90 recently diverged species on microbiota composition is still poorly documented [42].

91 Therefore, the main goal of this study is to document the transient intestinal microbiota

92 taxonomic composition of Lake Whitefish species pairs and their hybrids in natural and

93 controlled environment. First, we investigated the transient intestinal microbiota in five wild

94 species pairs of whitefish to estimate the within- and between-lake variation and tested for

95 parallelism among transient intestinal microbiota. Secondly, we characterized the taxonomic

96 composition of transient intestinal microbiota on dwarf, normal and first-generation hybrids

97 reared in common garden in order to test the influence of the whitefish host on the microbiota in

98 the same controlled conditions and under two different diets. 


\section{Methods}

\section{Sample collection for wild whitefish}

Lake Whitefish were sampled in 2013 using gill nets in Cliff, Indian and Webster lakes in

102 Maine, USA, and in East and Témiscouata lakes in Québec, Canada from May to July (Table 1).

103 Fish were dissected in the field in sterile conditions as detailed previously [35]. Briefly, the

104 ventral belly surface of fish was rinsed with ethanol, non-disposable tools were rinsed with

105 ethanol and heated over a blow torch between samples. The intestine was cut at the hindgut end

106 level (posterior part of the intestine) and the digesta were aseptically squeezed to collect the

107 alimentary bolus. All samples of alimentary bolus were transported to the laboratory and kept at -

$10880^{\circ} \mathrm{C}$ until further processing.

109

\section{Experimental crosses, rearing conditions and sample collection for captive whitefish}

In November 2013, 32 fish representing four cross types; dwarf (D우 × D ㅈ), Normal (N 우

$\left.\times \mathrm{N}^{\top}\right)$, and their reciprocal hybrids $\left(\mathrm{F} 1 \mathrm{D}\right.$ 우 $\times \mathrm{N}^{\top}$ and $\mathrm{F} 1 \mathrm{~N}$ 우 $\left.\times \mathrm{D} \boldsymbol{\sigma}^{\top}\right)$ were pooled together in

113 three tanks (eight whitefish per form per tank). Experimental cross design was described

114 previously [29, 31]. The protocol used for whitefish eggs fertilization and creating the parental

115 generation is detailed in the Supplementary Data. Fish were separated in three tanks sharing the

116 same experimental conditions (water, food, $\mathrm{pH}$ and temperature) for seven months. Juvenile

117 whitefish were fed on two types of food; Artemia and dry food pellet BioBrood (Bio-Oregon®)

$118[43,44]$. Although the fish were pooled without being marked, they were differentiated following

119 genetic allocation to a host group based on mitochondrial (mtDNA) and nuclear DNA

120 (Supplementary Data). In June 2014, fish were euthanatized with MS-222 and were dissected

121 immediately in sterile conditions, with the same protocol and sterile tools as for wild whitefish.

122 Samples were kept at $80^{\circ} \mathrm{C}$ until further processing. This study was approved under Institutional

123 Animal Care and Use Committee protocol 2008-0106 at Laval University. 


\section{Whitefish microbiota: DNA extraction, amplification and sequencing}

125 The alimentary boluses from captive and wild fish were extracted using a modification of

126 the QIAmp@ Fast DNA stool mini kit (QIAGEN). To maximize DNA extraction of gram-

127 positive bacteria, temperature and time were increased during the incubation steps and all

128 products used were doubled (Proteinase K, Buffer AL and ethanol 100\%). Thus, $1200 \mu$ were

129 transferred into the column (in two subsequent steps) and bacterial DNA was eluted from the

130 column with $100 \mu$ l of ultrapure water (DEPC-treated Water Ambion®). DNA extractions were

131 quantified with a Nanodrop (Thermo Scientific) and stored at $-20^{\circ} \mathrm{C}$ until use. Five blank

132 extractions were also done as negative controls.

In order to construct the community library, a region $~ 250$ bp in the 16S rRNA gene,

covering the V3-V4 region, was amplified using specific primers with Illumina barcoded adapters Bakt_341F-long and Bakt_805R-long in a dual indexed PCR approach [45]. The PCR amplification comprised $50 \mu 1$ PCR amplification mix containing $25 \mu 1$ of NEBNext Q5 Hot Start

137 Hifi PCR Master Mix, $1 \mu \mathrm{l}(0.2 \mu \mathrm{m})$ of each specific primers (Bakt_341F-long and Bakt_805R138 long), $15 \mu \mathrm{l}$ of sterile nuclease-free water and $8 \mu 1$ of specify amount of DNA. The PCR program 139 consisted of an initial denaturation step at $98^{\circ} \mathrm{C}$ for 30 s, followed by 30 cycles, where one cycle 140 consisted of $98^{\circ} \mathrm{C}$ for $10 \mathrm{~s}$ (denaturation), $56^{\circ} \mathrm{C}$ for $30 \mathrm{~s}$ (annealing) and $72^{\circ} \mathrm{C}$ for $45 \mathrm{~s}$ (extension), 141 and a final extension of $72^{\circ} \mathrm{C}$ for $5 \mathrm{~min}$. Negative and positive controls were also performed using 142 the same program.

143 All PCR results, including negative controls, were purified using the AMPure bead

144 calibration method. The purified samples were quantified using a fluorometric kit (QuantIT

145 PicoGreen; Invitrogen), pooled in equimolar amounts, and sequenced paired-end using Illumina

146 MiSeq at the Plate-forme d'analyses génomiques (IBIS, Université Laval, Québec, Canada). To

147 prevent focusing, template building, and phasing problems due to the sequencing of low diversity

148 libraries such as $16 \mathrm{~S}$ amplicons, 50\% PhiX genome was spiked in the pooled library. 


\section{Amplicon analysis}

Raw forward and reverse reads were quality trimmed, assembled into contigs for each

152 sample, and classified using Mothur v.1.36.0 following the protocol of MiSeq SOP

153 (https://www.mothur.org/wiki/MiSeq_SOP) [46, 47]. In brief, contigs were quality trimmed with

154 several criteria. First, a maximum of two mismatches were allowed when aligning paired ends

155 and ambiguous bases were excluded. Second, homopolymers of more than eight, sequences with

156 lengths less than $400 \mathrm{bp}$ and greater than $450 \mathrm{bp}$, sequences from chloroplasts, mitochondria and

157 nonbacterial were removed. Thirdly, chimeric sequences were found and removed using the

158 UCHIME algorithm [48]. Moreover, the database SILVA was used for the alignment and the

159 database RDP (v9) was used to classify the sequences with a 0.03 cut-off level. The Good's

160 coverage index which was used to evaluate the quality of the sequencing depth, was estimated in

161 Mothur [49].

\section{Statistical analyses}

The analyses for the captive and wild whitefish microbiota were performed with Mothur

165 and Rstudio v3.3.1 [50]. We first constructed a matrix of taxonomic composition (wild and

166 captive included) with the number of Operational taxonomic units (OTUs) after merging them by

167 genus. The bacterial genera were considered as variables and fish as objects according to Mothur

168 taxonomy files (stability.an.shared and stability.an.cons.taxonomy).

169 We then investigated the microbiota difference between the captive and wild whitefish

170 using a network analysis. A Spearman's correlation matrix following a Hellinger transformation

171 on the matrix of taxonomic composition was performed to document interactions between all

172 captive and wild whitefish microbiota. More precisely, a Spearman's correlation value (threshold

$173 \geq 0.5$ ), a P-value and Bonferroni correction was calculated for each sample. The network was

174 visualized using Cytoscape v3.2.1 [51], where nodes were illustrated in two different versions: (i)

175 according to their sampling sites (eight groups: five lakes and three tanks) and (ii) according to 
176 their genetic group (the two wild species pairs and the four captive groups: dwarf, normal,

177 reciprocal hybrid $\mathrm{F} 1 \mathrm{D}$ 우 $\mathrm{N}{ }^{\top}$, and hybrid $\mathrm{F} 1 \mathrm{~N}$ 우 $\mathrm{D} \overbrace{}^{\top})$. We also tested for the effect of captivity

178 (wild and captive conditions) on whitefish microbiota taxonomic composition (PERMANOVAs;

17910,000 permutations) and alpha diversity (inverse Simpson diversity) with an ANOVA following

180 a fitted Gaussian family generalized model (GLM) [52]. This was performed on all fish, on dwarf

181 whitefish only and on normal whitefish only. Finally, we documented the bacterial core of

182 whitefish by identifying the bacterial genera present in $80 \%$ of all fish.

To document variation within and among wild whitefish populations, we tested for an

184 effect of 'host species', 'lake' and their interaction, with 'body mass' as a covariate on the

185 taxonomic composition, using a permutational analysis of variance (PERMANOVA; 10,000

186 permutations). This procedure was run for each of the five lakes independently after removing the

187 explanatory variable 'lake' of the analysis. The 'host species', 'lake' effects and their interaction

188 on the inverse Simpson diversity were also tested using an analysis of variance (ANOVA)

189 following a fitted Gaussian family generalized model (GLM). Allometric effect on inverse

190 Simpson diversity was first tested with a linear regression on body mass. As for the taxonomic

191 composition, we ran this procedure for each lake independently. We also tested for differences in

192 microbiota taxonomic composition between dwarf and normal wild whitefish by means of a

193 discriminant analysis. First, a principal component analysis (PCA) on the transformed Hellinger

194 matrix was conducted to avoid collinearity and over fitting problem. Only the axes explaining at

195 least $1 \%$ of the variation were kept for the discriminant analysis, which was validated according

196 to the method described in Evin et al. [53]. Furthermore, principal coordinates analyses (PCoAs)

197 was built on a Bray-Curtis distance matrix after a Hellinger transformation to visualize variation

198 at the genus level between dwarf and normal wild whitefish among and within the lakes [54, 55].

199 We then tested for differences in taxonomic composition between the four captive groups

200 by investigating the effect of 'host group' (Dwarf, Normal, hybrid F1 D 우 N ð’, and hybrid F1 N 


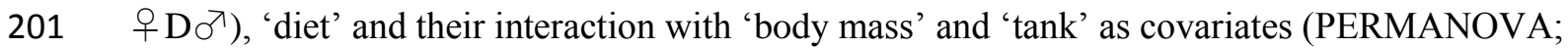

20210,000 permutations). The effect of diet was added in the analysis because fish bolus exhibited a

203 clear distinction between two observed feeding habits during the controlled experiment (A:

204 feeding on a mix of dry food and Artemia, B: feeding on Artemia only). For the alpha diversity,

205 the effect of 'host group', 'diet' and their interaction on the inverse Simpson diversity were tested

206 with a mixed effects linear random model using the 'nlme' package in $\mathrm{R}$, with tank as a random

207 effect and individual fish nested within tank [56]. As for the analyses on wild whitefish, we first

208 tested for an allometric relationship with body mass using a linear regression and used the

209 residuals in all cases showing a significant relationship. Principal coordinates analyses (PCoAs)

210 built on a Bray-Curtis distance matrix after a Hellinger transformation were also used to visualize

211 variation at the genus level as described above. Discriminant analyses were also performed on

212 captive whitefish but results were not displayed because of a negative cross-validation according

213 to Evin et al. [53]. Moreover, in order to test for the presence of bacterial genera that were private

214 to any of the captive whitefish group, we used the Metastats software with standard parameters ( $\mathrm{p}$

$215 \leq 0.05$ and number of permutations $=1000)$ to detect differential abundance of bacteria at the

216 genus level between two host populations [57]. Four Metastats analyses were performed on the

217 captive whitefish between: Dwarf vs. Normal, Dwarf vs. hybrid F1 D 우 N ○`, Normal vs. hybrid

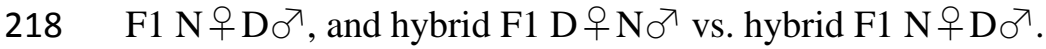




\section{Results}

\section{Sequencing quality}

A total of 2,498,271 sequences were obtained after trimming for the entire data set

222 composed of 185 whitefish intestinal microbiota (67 dwarf whitefish, 79 normal whitefish and 39

223 hybrids whitefish) from wild and captive populations (Table S1). A total of 189,683 operational

224 taxonomic units (OTUs) were identified with a 97\% identity threshold, representing 710 bacterial

225 genera. Two wild whitefish samples were removed because of low coverage and low number of

226 sequences and 22 captive whitefish samples were not included from various reasons (empty

227 intestine, no PCR amplification or ambiguous genetic allocation to a host group).

228 The average Good's coverage estimation for all intestinal microbiota (wild and captive

229 whitefish) was $92.3 \pm 7.6 \%$. While this may seem relatively low, the Good's coverage from wild

230 whitefish microbiota $(\mathrm{n}=111)$ and captive whitefish microbiota with a diet of Artemia only $(\mathrm{n}=27)$

231 were respectively $95.4 \pm 2.8 \%$ and $98.2 \pm 1.4 \%$, thus indicating a good sequencing quality of our

232 data. The low Good's coverage essentially came from captive whitefish microbiota with a mixed

233 diet of Artemia and dry food $(n=47)$, with a coverage index of $82.8 \pm 3.4 \%$. This data was

234 considered reliable for further analysis for three reasons. First, this second diet group was

235 composed of 341 bacterial genera in which the distribution showed an unusual high abundance

236 (i.e. number of reads) for a few genera (Table S2), which is known to decrease the Good's

237 coverage which is defined as 1-(Number of OTUs that have been sampled once / total number of

238 sequences) [49]. Second, the Illumina MiSeq sequencing was performed in the same run for all

239 samples, thus supporting the absence of sequencing problem given the excellent coverage

240 obtained for the other groups. Third, a low Good's coverage is supposed to reflect a low number

241 of sequences per sample because of the different filtration steps which eliminated reads generated

242 by poor quality sequencing. Here, the low Good's coverage observed in the captive group that fed 
243 on a mixed diet shows a total number of sequences per sample similar to the other captive group

244 (Table S2).

246 Wild versus captive whitefish intestinal microbiota

We observed a pronounced differentiation in intestinal microbiota between wild and

248 captive whitefish based on the network analysis among all samples (Fig. 1). More specifically, a

249 first group comprised of the wild whitefish (only one dwarf and two normal all from East Lake

250 were excluded from this group). There was no clear pattern of differentiation between wild dwarf

251 and normal whitefish microbiota (Fig. S1) but all wild populations tended to cluster together and

252 distinctively from captive fish. The second and third groups were composed by all captive

253 whitefish with few interactions observed between them despite the fact that they both comprised

254 fish from all four groups (dwarf, normal and both reciprocal hybrids). This second level of

255 differentiation was based on diet variation between the two groups of captive fish (Fig. 1). The

256 differentiation between the wild and the captive fish was also supported by a significant effect of

257 captivity on taxonomic composition (PERMANOVA, $P<0.001$; Table 2 ) when performing

258 analysis using all fish, dwarf only and normal only, as well as on alpha diversity when using all

259 fish (ANOVA, $P<0.001$; Table S3). Furthermore, although the relative abundance of major

260 phyla of Firmicutes, Proteobacteria, Actinobacteria and Planctomycetes was similar between

261 wild and captive whitefish, the bacterial abundance was clearly different between them (Fig. 2).

262 Finally, among the 710 bacterial genera found among all captive and wild whitefish, six bacterial

263 genera were shared by all fish: Acinetobacter, Aeromonas, Clostridium, Legionella,

264 Methylobacterium and Propionibacterium, which together constitute the core intestinal

265 microbiota defined as the microbial component shared by $80 \%$ of the samples. 


\section{Wild dwarf and normal whitefish microbiota}

269

270

271

272

273 dwarf and normal species were observed for less dominant phyla. For example, Tenericutes and

$274 \quad F u s o b a c t e r i a$ were more represented in normal whereas Bacteroidetes was more represented in

275 dwarf whitefish. We observed a more pronounced influence of the lake whereby dwarf or normal

276 microbiota within a given lake shared more similarities than microbiota from different lake

277 populations within a same species (Fig. 2). and results are ambiguous in Webster lake considering the low sample size (Fig. 4-F). a significant effect of both lake and host species on taxonomic composition (Table 2). The discriminant analysis performed on all wild whitefish also confirmed this overall difference between dwarf and normal intestinal microbiota albeit with overlap between them (Fig. 3).

Within each lake, the PERMANOVA tests revealed significant differences between dwarf and normal whitefish in three lakes (Cliff, East and Indian lakes) whereas no significant difference was observed in Témiscouata and Webster lakes (Table 2). Together, these observations suggested that the lake effect was more important than that of the host species. This is also supported by the PCoA analyses that revealed no global differentiation between all dwarf and normal whitefish intestinal microbiota (Fig. 4-A). Host effect is nevertheless also supported in lake specific PCoAs based on partially overlapping 95\% confidence interval in Cliff, East and Indian lakes (Fig. 4-B:D). Still, complete overlap was observed in Témiscouata lake (Fig. 4-E) 


\section{Pure and hybrid whitefish microbiota in controlled environment}

294 Although all fish were exposed to the same environment and the same food (both Artemia

295 and dry fish food), we observed that some whitefish did not feed on the dry fish food and ate only

296 live Artemia. As for the network analysis, the two distinct diet groups were evidenced by a

297 significant effect of diet on both taxonomic composition microbiotas (PERMANOVA, $\mathrm{P}<0.001$;

298 Table 2) and alpha diversity (ANOVA, $P=0.001$; Table S3). The PCoA analysis clearly

299 separated two distinct clusters on axis one corresponding to the two diet groups and independent

300 of the genetic background (either pure forms or hybrids) (Fig. 5). Furthermore, the mixed diet

301 group was dominated by Firmicutes and the Artemia diet group was dominated by Proteobacteria

302 (Fig. 2). The five main phyla composing the microbiota of the mixed diet group were in ranked

303 order Firmicutes, Proteobacteria, Actinobacteria, Bacteroidetes and TM7 whereas the five main

304 phyla of the Artemia diet group were Proteobacteria, Actinobacteria, Firmicutes, Planctomycetes

305 and TM7. Within the mixed diet group, lower abundance for Firmicutes, but higher for

306 Proteobacteria was observed in reciprocal hybrids in comparison to dwarf and normal whitefish.

307 Interestingly, the opposite pattern was observed for the Artemia diet group (i.e. hybrids bacterial

308 abundance was higher for Firmicutes but lower for Proteobacteria). The PERMANOVA tests

309 also revealed a significant effect of host group (Table 2). The PCoA analysis within each of the

310 two diet groups highlighted a modest differentiation based on overlapping 95\% confidence

311 interval between hybrids and pure whitefish (Fig. 5). In the mixed diet group, dwarf and normal

312 ellipses were mostly aligned on the second axis whereas the ellipses of the two hybrid groups

313 were mostly aligned on the first axis. The inverse pattern was observed in the Artemia diet group

314 with the ellipses of the pure whitefish those of hybrid whitefish aligned on the first and second

315 axis, respectively.

316 We observed between eight and 42 bacterial genera specific to a given whitefish group in

317 both diet groups (Fig. 6). We observed 21 dwarf-specific and 27 normal-specific bacterial genera 
318 respectively whereas the comparison between hybrids $\mathrm{F} 1 \mathrm{D}$ 우 $\mathrm{N}{ }^{\top 7}$ and $\mathrm{F} 1 \mathrm{~N}$ 우 $\mathrm{D}{ }^{\top}$ revealed 41

319 and 16 specific bacterial genera respectively. Finally, 135 specific bacteria genera to the mixed

320 diet group versus 62 to the Artemia diet group was also observed (see Table S4 for details).

\section{Discussion}

In this study, we compared the transient intestinal microbiota among five wild sympatric

324 species pairs of Lake Whitefish as well as captive dwarf, normal and hybrids whitefish reared in

325 identical controlled conditions. More specifically, we tested for (i) differences in intestinal

326 microbiota between dwarf and normal wild whitefish from the same lake; (ii) the occurrence of

327 parallelism among five wild sympatric species pairs, and (iii) differences in intestinal microbiota

328 among dwarf, normal and reciprocal hybrid whitefish which were reared together in identical

329 controlled conditions.

\section{The intestinal microbiota of captive versus wild whitefish}

Although an important part of bacteria which colonizes fish intestine may represent a

333 random sampling from water and food, the occurrence of intestinal microbiota cores have been

334 increasingly documented [58]. The intestinal microbiota cores represent OTUs or genera shared

335 among closed host relatives. The comparison between wild and captive whitefish highlighted six

336 genera shared by at least $80 \%$ of all samples. Interestingly, our intestinal core microbiota data

337 represented $20 \%$ of shared sequences which is higher than the intestinal microbiota core reported

338 for cichlid species (13-15\%) [39]. These shared genera could be horizontally transmitted and/or

339 selected as a common set of bacteria $[39,59]$. Although the captive whitefish were hatched in

340 captivity, their parents were of wild origin. Therefore, the conservation of certain genera by many

341 captive whitefish might corroborate the microbiota vertical transmission in fish. Finally, it is

342 noteworthy that we found many bacteria of unknown taxonomy (see Figure 2), and much more so 
343 in wild whitefish than in captive whitefish. This, along with previous studies, emphasizes that a

344 considerable number of bacteria is waiting to be discovered in natural freshwater ecosystems.

346 No clear pattern of parallel evolution in transient intestinal microbiota between dwarf and normal whitefish in the wild

Parallelism is the evolution of similar traits in independent populations [60] and has been

349 well documented in several sympatric species from temperate and sub-arctic lakes throughout the

350 north hemisphere [22, 61, 62]. Phenotypic parallelism between dwarf and normal whitefish has

351 previously been documented for morphological, physiological, behavioral, and ecological traits

$352[23,25,26,28-31,33,63]$. Given the difference in trophic and ecologic niches occupied by both

353 species [25, 64], we predicted that some level of parallelism in transient intestinal microbiota

354 would be observed between dwarf and normal whitefish species pairs. The dwarf whitefish is a

355 limnetic fish feeding on zooplankton whereas the normal whitefish is a benthic fish feeding on

356 zoobenthos and molluscs $[24,65]$. Therefore, we expected that a different diet should bring the

357 dwarf and normal whitefish of a given sympatric pair in contact with different bacterial

358 communities, leading to a distinct transient intestinal microbiota in a similar manner in the

359 different lakes. Moreover, differentiation of microbiota composition correlated with diet was

360 previously observed [66-70]. In fact, the use of novel diet elements frequently produced a change

361 in the microbiota composition by increasing or decreasing different bacterial strain according to

362 their metabolic potential [11]. This is also supported by the microbiota composition

363 differentiation of the two diet groups observed in captivity in this study. However, despite a

364 global effect of species host on microbiota, our results revealed no clear pattern of parallelism

365 among lakes. Indeed, difference between dwarf and normal whitefish microbiota composition

366 was observed in three of the five lakes only whereas no difference was observed in the other two

367 lakes. Together, this suggested that the environment has a more pronounced effect than the 
368 species host on the transient intestinal microbiota of dwarf and normal whitefish. These results

369 are in line with those obtained in a previous study in the same system but investigating kidney

370 microbiota [34]. Results of that study revealed that differences in bacteria composition between

371 dwarf and normal whitefish were not parallel among lakes. However, unlike this study and in

372 accordance with the higher diversity of prey types, normal whitefish kidney tissue consistently

373 had a more diverse bacterial community and this pattern was parallel among lakes. Together,

374 these results on whitefish microbiota add to building evidences from previous studies on this

375 system that the adaptive divergence of dwarf and normal whitefish has been driven by both

376 parallel and nonparallel ecological conditions across lakes. Moreover, the water bacterial

377 community of the same studied lakes was investigated previously and we found that each lake is

378 characterized by a specific water bacterial community [35]. This may reflect the differences in

379 both biotic and abiotic factors among these lakes [25, 64]. More specifically, Cliff, Webster and

380 Indian lakes are characterized by a greater oxygen depletion and a lower zooplankton densitiy

381 whereas East and Témiscouata lakes are characterized by more favorable environmental

382 conditions with a more important density of zooplankton and well-oxygenated water [64].

383 Therefore, the variation of water bacterial community along with the biotic and abiotic factors

384 could underlie the more important lake effect than species host effect observed in the transient

385 intestinal microbiota. Nevertheless, highly distinct bacterial composition between the water

386 bacterial community and the whitefish transient intestinal microbiota was observed among lakes.

387 The water bacterial community was dominated by Proteobacteria, Actinobacteria and

388 Bacteroidetes whereas the whitefish transient intestinal microbiota was dominated by Firmicutes

389 and Proteobacteria [35]. Therefore, whitefish transient intestinal microbiota was not directly

390 reflective of its local environment, raising the hypothesis of a selective effect on microbiota

391 induced by host physiology, immunity and genetic background $[12,18]$. For instance, some

392 transient bacteria might contribute to digestion of host diet [40] and such bacteria may impact on

393 the transient intestinal microbiota composition by increasing their abundance [11]. 


\section{Comparison of transient and adherent intestinal microbiota in wild whitefish and}

\section{5 the host effect}

The most prevalent phyla in wild whitefish transient microbiota are Acidobacteria, reported in previous studies of freshwater fishes [71-76]. In a previous study on adherent

400 intestinal microbiota, (that is adherent to the intestinal mucosa) performed on the same

401 individuals, we found that while the major phyla being represented were similar, the abundance 402 of some of them was different [35]. For example, the five first phyla for the adherent microbiota 403 were Proteobacteria (39.8\%), Firmicutes (19\%), Actinobacteria (5.1\%), OD1 (3.8\%) and

404 Bacteroidetes (2.8\%) whereas the five first phyla for the transient microbiota were Firmicutes 405 (38.2\%), Proteobacteria (29.5\%), Verrucomicrobia (4.4\%), Planctomycetes (4.1\%) and

406 Actinobacteria (3.7\%). Moreover, the number of genera and the number of OTUs were much 407 more important in the transient microbiota (611 genera and 94,883 OTUs) than the adherent 408 microbiota (421 genera and 10,324 OTUs). Most of the adherent bacterial taxa living on the 409 intestinal mucosa are not randomly acquired from the environment [77], but are rather retained by 410 different characteristics of the host [13]. It was also reported that there is an important host effect 411 in both dwarf and normal whitefish, which stabilizes the number of bacterial genera living in the

412 intestinal mucosa [35]. Thus, the comparison between whitefish transient and adherent microbiota

413 supports the view that the whitefish host have a substantial selective effect on its intestinal

414 microbiota. For instance, dwarf and normal whitefish in Cliff and East lakes show a distinct

415 intestinal microbiota for both the adherent and the transient bacteria. It is also noteworthy that the 416 adherent, but not the transient intestinal microbiota differed between species in Témiscouata Lake 417 whereas the exact opposite was observed in Indian Lake. In Témiscouata Lake, this difference in 418 adherent microbiota between species suggested a host-species effect leading to differential 
419 abundance of the same bacterial taxa. In contrast, results in Indian Lake suggest that host species

420 have no clear effect on microbiota divergence and that the difference in transient microbiota is

421 likely caused by the trophic niches occupied by each species. Altogether, these observations

422 suggest that the direction and intensity of factors determining the composition of intestinal

423 microbiota may differ between the host and the microbiota of a given holobiont system, as

424 previously reported [7]. Here, three distinct host-microbiota interactions may have evolved

425 independently in postglacial time: (i) divergence of intestinal microbiota influenced by the host

426 and the environment (Cliff and Est lakes), (ii) divergence of the intestinal microbiota mostly

427 influenced by the host (Témiscouata Lake), (iii) divergence of intestinal microbiota mostly

428 influenced by the environment (Indian Lake). Finally, given the pronounced difference that may

429 exist between transient and adherent microbiota, our results suggest that adherent microbiota is a

430 more reliable choice to study the effect of host species on microbiota than the analysis of transient

431 microbiota.

\section{Modest but significant host effect on the transient intestinal microbiota in controlled}

\section{4 conditions}

435 An unplanned variation in our experimental set up occurred during the captive rearing of

436 the whitefish pair species and the reciprocal hybrids during seven months, which led to the

437 unexpected observation of a diet preference which split the whitefish into two groups

438 independently of the parental or hybrid origin or the tanks where fish were. The use of two types

439 of food, Artemia and dry pellets, are usually recommended for optimizing growth and survival of

440 juvenile whitefish in captivity $[43,44]$. However, while 47 whitefish opted to feed on both types

441 of diet, 27 chose to feed only on Artemia. This allowed us to assess the impact of different diets

442 in an otherwise identical controlled environment, which revealed that diet had the most profound 
443 impact on the community composition of transient intestinal microbiota in a controlled

444 environment.

445 Nevertheless, we did observe a significant, albeit modest effect of whitefish genetic hosts on the

446 transient intestinal microbiota. In principle, in a controlled environment, there should be no

447 environmental effect on the microbiota composition and consequently, variation in microbiota

448 should only depend on the host effect which integrated the influence of the host physiology,

449 immunity, as well as genetic background. Here, while the PCoA analysis only revealed a slight

450 pattern of differentiation between both parental species and their reciprocal hybrids, the

451 PERMANOVA test revealed a statistically significant effect of the host genetic background on

452 the taxonomic composition of the transient microbiota. This was accompanied by a significant

453 variation in bacterial abundance at the phylum level, especially within the diet group A (feeding

454 on both Artemia and dry pellets). Finally, numerous genera that were specific to one whitefish

455 species or the hybrids were observed in both diet groups. These results suggest an effect of

456 hybridization on the transient intestinal microbiota. This hybridization effect could be explain by

457 the genetic incompatibilities model of Bateson, Dobzhansky and Muller (BDM) previously

458 highlighted in the Lake Whitefish system [63, 78, 79]. To our knowledge, only one study

459 compared the intestinal microbiota among closely related fish populations in controlled

460 conditions [38] and none compared parental and hybrid progeny. Specifically, distinct intestinal

461 microbiota between two ecotypes of the Trinidadian Guppy (Poecilia reticulata) suggested a

462 pronounced effect of the genetic background [38]. However, these results should be interpreted

463 cautiously since fish used for this experiment were adults that were born in the wild and kept in

464 tanks for 10 weeks only. Consequently, the difference could reflect a carry-over effect from the

465 natural conditions whereas in our case, fish were born in captivity. 


\section{Conclusions}

468 In summary, we observed complex patterns of variation in the transient intestinal

469 microbiota of sympatric dwarf and normal whitefish in their natural environment, with little

470 evidence of parallelism among different populations of a same species. Local environment, more

471 than species explained the observed patterns of variation. Nevertheless, a possible host selective

472 effect was revealed by the pronounced contrast in the bacterial composition observed in water and

473 intestinal samples. Moreover, differences in taxonomic composition between sympatric species

474 were observed for three of the five lakes, suggesting specific but not parallel microbiota-host

475 association in these lakes. Finally, a possible host effect on its transient intestinal microbiota was

476 revealed by a modest, albeit significant genetic host effect (parental forms and reciprocal hybrids)

477 when reared in controlled conditions. However, a more prevalent effect of environmental factor

478 was highlighted by the pronounced difference observed among two diet groups. Overall, our

479 results support the view that the transient intestinal fish microbiota is the result of complex

480 interactions between the host's genetic background and environmental conditions such as trophic

481 resources. The fact that we observed stronger environmental effect on the microbiota among five

482 sympatric whitefish pairs illustrates that drawing generalization regarding host-microbiota

483 association for a given species may be difficult, and in fact inappropriate. 


\section{Acknowledgements}

485 We thank G. Côté, A. Dalziel, A-M. Dion-Côté, S. Higgins and J-C Therrien for fieldwork and

486 technical assistance for crossing and rearing of captive whitefish at the LARSA. We are grateful

487 to C. Hernandez-Chàvez for laboratory advice and support, B. Boyle for his help with the

488 Illumina MiSeq sequencing. 


\section{References}

491 1. Stein LD. Human genome: end of the beginning. Nature. 2004; 431:915-916.

492 2. Sagan L. On the origin of mitosing cells. J Theor Biol. 1967; 14:225-274.

493 3. Nowak MA. Five rules for the evolution of cooperation. Science. 2006; 314:1560.

494 4. Gilbert SF, Sapp J, Tauber AI. A symbiotic view of life: we have never been individuals. Q

495 Rev Biol. 2012; 87:325.

496 5. Hooper LV, Wong MH, Thelin A, Hansson L, Falk PG, Gordon JI. Molecular analysis of

497 commensal host-microbial relationships in the intestine. Science. 2001; 291.

498 6. Rawls JF, Samuel BS, Gordon JI. Gnotobiotic zebrafish reveal evolutionarily conserved

499 responses to the gut microbiota. Proc Natl Acad Sci USA. 2004; 101.

500 7. Rosenberg E, Zilber I. Microbes drive evolution of animals and plants: the hologenome

501 concept. mBio. 2016; 7:e01395-15.

502 8. Hanif A, Bakopoulos V, Dimitriadis GJ. Maternal transfer of humoral specific and non-specific

503 immune parameters to sea bream (Sparus aurata) larvae. Fish Shellfish Immunol. 2004; 17.

504 9. Wilkins L, Rogivue A, Fumagalli L, Wedekind C. Declining diversity of egg-associated

505 bacteria during development of naturally spawned whitefish embryos (Coregonus spp.). Aquat

506 Sci. 2015; 77:481-97.

507 10. Llewellyn MS, Boutin S, Hoseinifar SH, Derome N. Teleost microbiomes: the state of the art 508 in their characterization, manipulation and importance in aquaculture and fisheries. Front

509 Microbiol. 2014; 5:207.

510 Rosenberg E, Zilber I. The hologenome concept: human, animal and plant microbiota.

511 Switzerland: Springer; 2013.

512 12. Alberdi A, Aizpurua O, Bohmann K, Zepeda-Mendoza ML, Gilbert TP. Do vertebrate gut

513 metagenomes confer rapid ecological adaptation? Trends Ecol Evol. 2016; 31.

514 13. Brucker RM, Bordenstein SR. Speciation by symbiosis. Trends Ecol Evol. 2012; 27.

515 14. Damodaram K, Ayyasamy A, Kempraj V. Commensal bacteria aid mate-selection in the Fruit 516 Fly, Bactrocera dorsalis. Microb Ecol. 2016; 72.

517 15. Shropshire JD, Bordenstein SR. Speciation by symbiosis: the microbiome and behavior.

518 mBio. 2016; 7:e01785-15.

519 16. Muller HJ. Isolating mechanisms, evolution and temperature. Biol Symp. 1942; 6:71-125.

520 17. Dobzhansky T: Genetics and the origin of species. Columbia university press; 1937. 
521 18. Macke E, Tasiemski A, Massol F, Callens M, Decaestecker E. Life history and eco-

522 evolutionary dynamics in light of the gut microbiota. Oikos. 2017; 126.

523 19. Nelson JS: Fishes of the World. 4Th Eds. New York: Wiley; 2006.

524 20. Béné C, Barange M, Subasinghe R, Subasinghe R, Pinstrup-Andersen P, Merino G, Hemre

525 GI, Williams M. Feeding 9 billion by 2050-Putting fish back on the menu. FOOD SECUR. 2015;

5267.

527 21. Clements KD, Angert ER, Montgomery WL, Choat JH. Intestinal microbiota in fishes: what's 528 known and what's not. Mol Ecol. 2014; 23:1891.

529 22. Bernatchez L, Renaut S, Whiteley AR, Derome N, Jeukens J, Landry L, Lu G, Nolte AW, 530 Østbye K, Rogers SM, St-Cyr J. On the origin of species: insights from the ecological genomics 531 of Lake Whitefish. Philos Trans R Soc Lond B Biol Sci. 2010; 365:1783-800.

532 23. Lu G, Bernatchez L. Experimental evidence for reduced hybrid viability between dwarf and 533 normal ecotypes of Lake Whitefish (Coregonus clupeaformis Mitchill). Philos Trans R Soc Lond 534 B Biol Sci. 1998; 265:1400.

535 24. Bodaly RA. Morphological and ecological divergence within the Lake Whitefish (Coregonus 536 clupeaformis) species complex in Yukon Territory. J Fish Board Can. 1979; 36:1214.

537 25. Landry L, Bernatchez L. Role of epibenthic resource opportunities in the parallel evolution of 538 Lake Whitefish species pairs (Coregonus sp.). J Evol Biol. 2010; 23:2602-13.

539 26. StCyr J, Derome N, Bernatchez L. The transcriptomics of life-history trade-offs in whitefish $540 \quad$ species pairs (Coregonus sp.). Mol Ecol. 2008; 17:1850-70.

541 27. Dalziel AC, Laporte M, Rougeux C, Guderley H, Bernatchez L. Convergence in organ size 542 but not energy metabolism enzyme activities among wild Lake Whitefish (Coregonus 543 clupeaformis) species pairs. Mol Ecol. 2016; 26:225-44.

544 28. Jeukens J, Bittner D, Knudsen R, Bernatchez L. Candidate genes and adaptive radiation: 545 insights from transcriptional adaptation to the limnetic niche among coregonine fishes

546 (Coregonus spp., Salmonidae). Mol Biol Evol. 2009; 26:155-66.

547 29. Dalziel AC, Martin N, Laporte M, Guderley H, Bernatchez L. Adaptation and acclimation of 548 aerobic exercise physiology in Lake Whitefish ecotypes (Coregonus clupeaformis). Evolution. $549 \quad 2015 ; 69: 2167-86$.

550 30. Laporte M, Rogers SM, Dion AM, Normandeau E, Gagnaire PA, Dalziel AC, Chebib J, 551 Bernatchez L. RAD-QTL mapping reveals both genome-level parallelism and different genetic 552 architecture underlying the evolution of body shape in Lake Whitefish (Coregonus clupeaformis) 553 Species Pairs. G3-GENES GENOM GENET. 2015; 5:1481. 
554 31. Laporte M, Dalziel AC, Martin N, Bernatchez L. Adaptation and acclimation of traits

555 associated with swimming capacity in Lake Whitefish (Coregonus clupeaformis) ecotypes. BMC

556 Evol Biol. 2016; 16.

557 32. Gagnaire PA, Normandeau E, Pavey SA, Bernatchez L. Mapping phenotypic, expression and

558 transmission ratio distortion QTL using RAD markers in the Lake Whitefish (Coregonus

559 clupeaformis). Mol Ecol. 2013; 22.

560 33. Dalziel AC, Laporte M, Guderley H, Bernatchez L. Do differences in the activities of 561 carbohydrate metabolism enzymes between Lake Whitefish ecotypes match predictions from

562 transcriptomic studies? Comp Biochem Physiol Part B Biochem Mol Biol. 2017;

563 34. Sevellec M, Pavey SA, Boutin S, Filteau M, Derome N, Bernatchez L. Microbiome

564 investigation in the ecological speciation context of Lake Whitefish (Coregonus clupeaformis)

565 using next-generation sequencing. J Evol Biol. 2014; 27:1029.

566 35. Sevellec M, Derome N, Bernatchez L. Holobionts and ecological speciation: the intestinal

567 microbiota of Lake Whitefish species pairs. Microbiome. 2018; 6:47.

568 36. David LA, Maurice CF, Carmody RN, Gootenberg DB, Turnbaugh PJ. Diet rapidly and 569 reproducibly alters the human gut microbiome. Nature. 2014; 505.

570 37. Baldo L, Pretus JL, Riera JL, Musilova Z, Nyom ARB, Salzburger W. Convergence of gut 571 microbiotas in the adaptive radiations of African cichlid fishes. ISME J. 2017;

$572 \quad 10.1038 /$ ismej.2017.62

573 38. Sullam KE, Rubin B, Dalton CM, Kilham SS, Flecker AS, Russell JA. Divergence across

574 diet, time and populations rules out parallel evolution in the gut microbiomes of Trinidadian

575 guppies. ISME J. 2015; 9.

576 39. Baldo L, Riera JL, Tooming-Klunderud A, Albà MM, Salzburger W. Gut microbiota

577 dynamics during dietary shift in Eastern African Cichlid Fishes. PloS one. 2015; 10:e0127462.

578 40. Smith C, Snowberg LK, Caporaso JG, Knight R, Bolnick DI. Dietary input of microbes and

579 host genetic variation shape among-population differences in stickleback gut microbiota. ISME J.

$580 \quad 2015 ; 9: 2515$.

581 41. Hata H, Tanabe AS, Yamamoto S, Toju H, Kohda M, Hori M. Diet disparity among

582 sympatric herbivorous cichlids in the same ecomorphs in Lake Tanganyika: amplicon

583 pyrosequences on algal farms and stomach contents. BMC Biol. 2014; 12:90.

584 42. Guivier E, Martin J-F, Pech N, Ungaro A, Chappaz R, Gilles A. Microbiota diversity within

585 and between the tissues of two wild interbreeding species. Microb Ecol. 2017; 75:799-810.

586 43. Flüchter J. Substance essential for metamorphosis of fish larvae extracted from Artemia.

587 Aquaculture. 1982; 27:83. 

larvae fed only formulated dry diets. Aquaculture. 1988; 69:105.

590 45. Klindworth A, Pruesse E, Schweer T. Evaluation of general 16S ribosomal RNA gene PCR 591 primers for classical and next-generation sequencing-based diversity studies. Nucleic Acids Res. 592 2012; 41:e1.

593 46. Schloss PD, Westcott SL, Ryabin T. Introducing mothur: open-source, platform-independent, 594 community-supported software for describing and comparing microbial communities. Appl 595 Environ Microbiol. 2009; 75:7537.

596 47. Kozich JJ, Westcott SL, Baxter NT, Highlander SK, Schloss PD. Development of a dual597 index sequencing strategy and curation pipeline for analyzing amplicon sequence data on the 598 MiSeq Illumina sequencing platform. Appl Environ Microbiol. 2013; 79:5112.

599 48. Edgar RC, Haas BJ, Clemente JC, Quince C, Knight R. UCHIME improves sensitivity and 600 speed of chimera detection. Bioinformatics. 2011; 27.

601 49. Hurlbert SH. The nonconcept of species diversity: a critique and alternative parameters. Ecol 602 Appl. 1971; 52.

603 50. Team RS: RStudio. Integrated development for R. Boston: RStudio Inc. 2015.

604 51. Shannon P, Markiel A, Ozier O, Baliga NS, Wang JT, Ramage D, Amin N, Schwikowski1 B, 605 Ideker T. Cytoscape: a software environment for integrated models of biomolecular interaction 606 networks. Genome Res. 2003; 13:2498.

607 52. Magurran AE. Measuring Biological Diversity. Oxford: Blackwell Science Ltd; 2004.

608 53. Evin A, Cucchi T, Cardini A, Vidarsdottir US, Larson G, Dobney K. The long and winding 609 road: identifying pig domestication through molar size and shape. J Archaeol Sci. 2013; 40.

610 54. Oksanen J, Kindt R, Legendre P, O'hara B, Stevens HH. Vegan: Community ecology 611 package. R package ver. 2.0-10. 2013

612 55. Legendre P, Legendre L. Numerical Ecology. 2Nd. Amsterdam: Elsevier Science; 1998.

613 56. Pinheiro J, Bates D, DebRoy S, Sarkar D, Team RC. nlme: Linear and nonlinear mixed 614 effects models. Biometrics. 2009; 3:96.

615 57. White JR, Nagarajan N, Pop M. Statistical methods for detecting differentially abundant 616 features in clinical metagenomic samples. PLoS Comput Biol. 2009; 5:e1000352.

617 58. Astudillo-García C, Bell JJ, Webster NS, Glasl B, Jompa J, Montoya JM, Taylor MW. 618 Evaluating the core microbiota in complex communities: A systematic investigation. Environ 619 Microbiol. 2017; 19:1450. 
59. Rawls JF, Mahowald MA, Ley RE, Gordon JI. Reciprocal gut microbiota transplants from zebrafish and mice to germ-free recipients reveal host habitat selection. Cell. 2006; 127.

60. Schluter D, Nagel LM. Parallel speciation by natural selection. Am Nat. 1995; 146.

61. Schluter D. Ecological character displacement in adaptive radiation. Am Nat. 2000; 156:4-16.

62. Østbye K, Amundsen PA, Bernatchez L, Klemetsen A, Knudsen R, Kristoffersen R, Naesje TF, Hindar K. Parallel evolution of ecomorphological traits in the European whitefish Coregonus lavaretus (L.) species complex during postglacial times. Mol Ecol. 2006; 15.

63. Dion-Cote AM, Renaut S, Normandeau E, Bernatchez L. Article RNA-seq Reveals Transcriptomic shock involving transposable elements reactivation in hybrids of young Lake Whitefish species. Mol Biol Evol. 2014; 31:1188.

64. Landry L, Vincent WF, Bernatchez L. Parallel evolution of Lake Whitefish dwarf ecotypes in association with limnological features of their adaptive landscape. J Evol Biol. 2007; 20:971.

65. Bernatchez L, Chouinard A, Lu G. Integrating molecular genetics and ecology in studies of adaptive radiation: whitefish, Coregonus sp., as a case study. Biol J Linnean Soc. 1999; 68:173.

66. Haygood AM, Jha R. Strategies to modulate the intestinal microbiota of Tilapia (Oreochromis $s p$.) in aquaculture: a review. REV AQUACULT. 2016; 1.

67. Zarkasi KZ, Taylor RS, Abell G, Tamplin ML, Glencross BD, Bowman JP. Atlantic salmon (Salmo salar L.) gastrointestinal microbial community dynamics in relation to digesta properties and diet. Mol Ecol. 2016; 71:589.

68. David CJ, Veena R, Kumaresan G. High cholesterol diet induces obesity in Zebrafish. PloS one. 2016; 8:e66970.

69. Nayak SK. Role of gastrointestinal microbiota in fish. Aquac Res. 2010; 41:1553-73.

70. Koo H, Hakim JA, Powell ML, Kumar R, Eipers PG, Morrow CD, Crowley M, Lefkowitz EJ, Watts SA, Bej AK. Metagenomics approach to the study of the gut microbiome structure and function in zebrafish Danio rerio fed with gluten formulated diet. J Microbiol Methods. 2017; 135.

71. Larsen AM, Mohammed HH. Characterization of the gut microbiota of three commercially valuable warmwater fish species. J Appl Microbiol. 2014; 116:1396.

72. Li XM, Zhu YJ, Yan QY, Ring $\varnothing$ E, Yang DG. Do the intestinal microbiotas differ between paddlefish (Polyodon spathala) and bighead carp (Aristichthys nobilis) reared in the same pond? J Appl Microbiol. 2014; 117.

73. Ye L, Amberg J, Chapman D, Gaikowski M, Liu WT. Fish gut microbiota analysis differentiates physiology and behavior of invasive Asian carp and indigenous American fish. ISME J. 2014; 10:2076. 
654 74. Roeselers G, Mittge EK, Stephens WZ, Parichy DM, Cavanaugh CM, Guillemin K, Rawls JF. 655 Evidence for a core gut microbiota in the zebrafish. ISME J. 2011; 5.

656 75. Eichmiller JJ, Hamilton MJ, Staley C, Sadowsky MJ, Sorensen PW. Environment shapes the 657 fecal microbiome of invasive carp species. Microbiome. 2016; 4:44.

658 76. Sullam KE, Essinger SD, Lozupone CA, O’Connor MP, Rosen GL, Knight R, Kilham SS, 659 Russell GA. Environmental and ecological factors that shape the gut bacterial communities of 660 fish: a meta-analysis. Mol Ecol. 2012; 21(3):3363-78

661 77. Bolnick DI, Snowberg LK, Hirsch PE, Lauber CL. Individuals' diet diversity influences gut 662 microbial diversity in two freshwater fish (Threespine stickleback and Eurasian perch). Ecol Lett. $6632014 ; 17: 979$.

664 78. Gagnaire PA, Pavey SA, Normandeau E, Bernatchez L. The genetic architecture of 665 reproductive isolation during speciation-with-gene-flow in Lake Whitefish species pairs assessed 666 by rad sequencing. Evolution. 2013; 67:2483.

667 79. Renaut S, Nolte AW, Bernatchez L. Gene expression divergence and hybrid misexpression 668 between Lake Whitefish species pairs (Coregonus spp. Salmonidae). Mol Biol Evol. 2009; 26: $669 \quad 925-936$

670 80. Rogers SM, Isabel N, Bernatchez L. Linkage maps of the dwarf and normal Lake Whitefish 671 (Coregonus clupeaformis) species complex and their hybrids reveal the genetic architecture of 672 population divergence. Genetics. 2007; 175(1): 375-398.

673 81. Aljanabi SM, Martinez I. Universal and rapid salt-extraction of high quality genomic DNA 674 for PCR-based techniques. Nucleic Acids Res. 1997; 25.

675 82. Valiquette E, Perrier C, Thibault I, Bernatchez L. Loss of genetic integrity in wild Lake Trout 676 populations following stocking: insights from an exhaustive study of 72 lakes from Québec, 677 Canada. Evol Appl. 2014; 7.

678 83. Jacobsen MW, Hansen MM, Orlando L, Bekkevold D, Bernatchez L, Willerslev E, Gilbert 679 MTP. Mitogenome sequencing reveals shallow evolutionary histories and recent divergence time 680 between morphologically and ecologically distinct European Whitefish (Coregonus spp.). Mol 681 Ecol. 2012; 21:2727-2742.

682 84. Rico C, Normandeau E, Dion AM, Côté G, Bernatchez L. Combining next-generation 683 sequencing and online databases for microsatellite development in non-model organisms. Sci 684 Rep. 2013; 3:3376.

685 85. Pritchard JK, Stephens M, Donnelly P. Inference of population structure using multilocus 686 genotype data. Genetics. 2000; 155.

687 86. Duchesne P, Godbout MH, Bernatchez L. PAPA (package for the analysis of parental 688 allocation): a computer program for simulated and real parental allocation. Mol Ecol Notes. 2002; 6892. 
690 87. Piry S, Alapetite A, Cornuet JM, Paetkau D, Baudouin L, Estoup A. GENECLASS2: a

691 software for genetic assignment and first-generation migrant detection. J Hered. 2004; 95.

692 88. Rannala B, Mountain JL. Detecting immigration by using multilocus genotypes. Proc Natl 693 Acad Sci USA. 1997; 94. 


\section{Tables}

Table 1 Number and locations of samples, sampling dates for each captive and wild whitefish populations or group. DD: dwarf whitefish, NN: normal whitefish, $\mathrm{DH}$ : hybrid F1 D우 $\times \mathrm{N}_{\text {○}}$, $\mathrm{NH}$ : hybrid $\mathrm{F} 1 \mathrm{~N}$ 우 $\times \mathrm{D}$ ○'.

\begin{tabular}{|c|c|c|c|c|}
\hline Origin & Form & $\begin{array}{c}\text { Sample } \\
\text { size }\end{array}$ & Sampling date & Coordinates \\
\hline \multirow{2}{*}{ Cliff } & DD & 12 & June $13-14^{\text {th }}$ & \multirow{2}{*}{$46^{\circ} 23^{\prime} 59^{\prime \prime} \mathrm{N}, 69^{\circ} 15^{\prime} 11^{\prime \prime W}$} \\
\hline & $\mathrm{NN}$ & 12 & 2013 & \\
\hline \multirow{2}{*}{ East } & $\mathrm{DD}$ & 10 & \multirow{2}{*}{ July $2-4^{\text {th }} 2013$} & \multirow{2}{*}{$47^{\circ} 11^{\prime} 15^{\prime \prime} \mathrm{N}, 69^{\circ} 33^{\prime} 41^{\prime \prime W}$} \\
\hline & NN & 13 & & \\
\hline \multirow{2}{*}{ Indian } & $\mathrm{DD}$ & 12 & June $10-11^{\text {th }}$ & \multirow{2}{*}{$46^{\circ} 15^{\prime} 32^{\prime \prime} \mathrm{N}, 69^{\circ} 17^{\prime} 29^{\prime \prime} \mathrm{W}$} \\
\hline & NN & 13 & 2013 & \\
\hline \multirow{2}{*}{ Témiscouata } & DD & 10 & May $28-30^{\text {th }}$ & \multirow{2}{*}{$47^{\circ} 40^{\prime} 04^{\prime \prime} \mathrm{N}, 68^{\circ} 49^{\prime} 03^{\prime \prime W}$} \\
\hline & $\mathrm{NN}$ & 14 & 2013 & \\
\hline \multirow{2}{*}{ Webster } & DD & 3 & June $12-13^{\text {th }}$ & \multirow{2}{*}{$46^{\circ} 09^{\prime} 23^{\prime \prime} \mathrm{N}, 6^{\circ} 04^{\prime} 52^{\prime \prime} \mathrm{W}$} \\
\hline & NN & 12 & 2013 & \\
\hline \multirow{4}{*}{$\begin{array}{l}\text { Common } \\
\text { Garden } 1\end{array}$} & $\mathrm{DD}$ & 7 & & \multirow{4}{*}{ LARSA } \\
\hline & $\mathrm{NN}$ & 5 & November & \\
\hline & $\mathrm{DH}$ & 7 & June $09^{\text {th }} 2014$ & \\
\hline & NH & 6 & & \\
\hline \multirow{4}{*}{$\begin{array}{l}\text { Common } \\
\text { Garden } 2\end{array}$} & DD & 5 & & \multirow{4}{*}{ LARSA } \\
\hline & NN & 4 & November & \\
\hline & DH & 6 & $\begin{array}{l}12^{\text {tin }} 2013 \text { to } \\
\text { June } 10^{\text {th }} 2014\end{array}$ & \\
\hline & $\mathrm{NH}$ & 6 & & \\
\hline \multirow{4}{*}{$\begin{array}{l}\text { Common } \\
\text { Garden } 3\end{array}$} & DD & 8 & \multirow{4}{*}{$\begin{array}{l}\text { November } \\
12^{\text {th }} 2013 \text { to } \\
\text { June } 11^{\text {th }} 2014\end{array}$} & \multirow{4}{*}{ LARSA } \\
\hline & $\mathrm{NN}$ & 6 & & \\
\hline & $\mathrm{DH}$ & 6 & & \\
\hline & $\mathrm{NH}$ & 8 & & \\
\hline
\end{tabular}


696 Table 2 Summary of PERMANOVA test statistics on microbiota taxonomic composition. First,

697 the fish group "wild" refers to the analysis of effect of host species (dwarf and normal), lake

698 (Cliff, East, Indian, Témiscouata and Webster) and its interaction with body mass as a covariate

699 on all wild fish. Second, the fish group "All lakes" tests the host species and body mass as a

700 covariate is treated for each lake separately. Third, the fish group "captive" refers to the analysis

701 of effect of host group (dwarf, normal, hybrids F1 D 우 $\mathrm{N}^{\urcorner}$and F1 N 우 D ${ }^{\top}$ ), diet (Artemia only

702 and mixed diet of live Artemia with dry food) and its interaction with body mass and tank as

703 covariates on all captive fish. Fourth, the fish group 'both' refers to the effect of captivity (wild

704 and captive) and body mass as covariate on all fish, dwarf only and normal only. F-Value: value 705 of the F statistic, $R^{2}$ : R-Squared Statistic, $\operatorname{Pr}(>F)$ : p-value.

\begin{tabular}{llrrr}
\hline \multirow{2}{*}{ Fish group } & Source of & \multicolumn{3}{c}{ PERMANOVA } \\
& variation & F-Value & $\mathrm{R}^{2}$ & $\operatorname{Pr}(>\mathrm{F})$ \\
\hline WILD & Species & & & \\
& Lake & 2.350 & 0.017 & 0.006 \\
All lakes & Species:Lake & 1.927 & 0.056 & $<0.001$ \\
& Body mass & 1.628 & 0.012 & 0.067 \\
& & & & \\
Cliff Lake & Species & 5.253 & 0.180 & $<0.001$ \\
& Body mass & 2.914 & 0.100 & $<0.001$ \\
East Lake & Species & 1.889 & 0.085 & 0.047 \\
Indian Lake & Body mass & 1.165 & 0.053 & 0.291 \\
Témiscouata Lake & Species & 2.032 & 0.083 & 0.041 \\
& Body mass & 1.582 & 0.064 & 0.105 \\
Webster Lake & Species & 0.741 & 0.033 & 0.732 \\
& Body mass & 0.920 & 0.041 & 0.447 \\
CAPTIVE & Species & 0.858 & 0.057 & 0.562 \\
& Body mass & 2.142 & 0.143 & 0.015 \\
& & & & \\
& Group & 1.985 & 0.043 & 0.033 \\
& Diet & 58.955 & 0.427 & $<0.001$ \\
& Species:Diet & 1.557 & 0.034 & 0.108 \\
& Body mass & 1.990 & 0.014 & 0.084 \\
& Tank & 1.649 & 0.024 & 0.102
\end{tabular}

BOTH

\begin{tabular}{llrlr} 
All fish groups & Captivity & 64.457 & 0.260 & $<0.001$ \\
& Body mass & 3.481 & 0.014 & 0.001 \\
Dwarf & Captivity & 28.245 & 0.289 & $<0.001$ \\
& Body mass & 4.517 & 0.046 & $<0.001$ \\
Normal & Captivity & 16.371 & 0.180 & $<0.001$ \\
& Body mass & 1.917 & 0.021 & 0.035 \\
\hline
\end{tabular}




\section{Figure legends}

706 Figure 1 Network analysis of intestinal microbiota of dwarf and normal wild whitefish and

707 intestinal microbiota of dwarf, normal and hybrids captive whitefish. Each node represents either

708 a dwarf, normal or hybrid whitefish microbiota. The connecting lines between two samples

709 represent their Spearman index correlation.

710 Figure 2 Relative abundance of phyla representatives found in intestinal microbiota for dwarf and

711 normal wild whitefish in each lake, as well as in intestinal microbiota for dwarf, normal and

712 hybrids whitefish in controlled condition. Taxonomy was constructed with the database Silva and

713 MOTHUR with confidence threshold at 97\%. For the wild whitefish, lakes are represented as C:

714 Cliff, E: East, I: Indian, T: Témiscouata, W: Webster and the whitefish species is represented as

715 D: dwarf and N: normal. For the captive fish, normal whitefish, dwarf whitefish and hybrids are

716 represented as $\mathrm{N} \times \mathrm{N}, \mathrm{D} \times \mathrm{D}, \mathrm{F} 1 \mathrm{D}$ 우 $\times \mathrm{N}_{\sigma^{\top}}$ and $\mathrm{F} 1 \mathrm{~N}$ 우 $\times \mathrm{D}_{\sigma^{\top}}$ respectively. Diet group $\mathrm{A}$ (Artemia

$717+$ dry food) and B (Artemia).

718 Figure 3 Discriminant analysis histogram of all wild whitefish microbiota. This discriminant

719 analysis was performed on the axes of principal component analysis (PCA) and T- tests were

720 performed on the results of the discriminant analysis. Dwarf and normal whitefish are represented

721 by the black and white bars, respectively. Dwarf and normal whitefish with overlapping

722 discriminant scores are shown in grey.

723 Figure 4 Principal coordinate analyses (PCoAs) within- and between lakes for the wild whitefish

724 microbiota. These PCoAs are based on Jaccard index after a Hellinger transformation. Ellipses of

$72595 \%$ confidence are illustrated and were done with dataEllips using R car package. A:

726 comparison among all wild whitefish populations from the five lakes. Each lake analyzed is

727 represented by a different symbol and ellipse color: Cliff Lake (red), East Lake (blue), Indian

728 Lake (orange), Témiscouata Lake (green) and Webster Lake (purple) and whitefish species is 
729 represented by symbols: Dwarf (circle) and Normal (cross). B-F: comparison between Dwarf and

730 Normal whitefish microbiota within each lake. Cliff Lake, East Lake, Indian Lake, Témiscouata

731 Lake and Webster Lake are represented by B, C, D, E and F respectively. Whitefish species is

732 represented by different symbols: dwarf (circle) and normal (cross); ellipses of 95\% confidence

733 are illustrated and were done with dataEllips using $\mathrm{R}$ car package. the red and green ellipses

734 represent the dwarf and normal species, respectively.

735 Figure 5 Principal coordinate analyses (PCoAs) between the microbiota of the four captive

736 whitefish groups. A: comparison between the four captive whitefish groups intestinal microbiota.

737 B: comparison between the four whitefish groups intestinal microbiota in the mixed diet group.

738 C: comparison between the four whitefish groups intestinal microbiota in the Artemia diet group.

739 Ellipses of $95 \%$ confidence were done with dataEllips using R car package. Each whitefish

740 species is represented by different symbols: dwarf $\left(\mathrm{D}\right.$ 우 $\left.\times \mathrm{D} \varsigma^{\urcorner}\right)$and normal $\left(\mathrm{N}\right.$ 우 $\left.\times \mathrm{N}_{\sigma^{\top}}\right)$ are

741 represented by circle a cross respectively and their ellipses are represented by continuous lines.

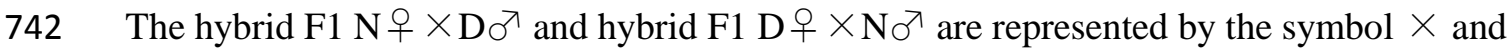

743 respectively and their ellipses are represented by dotted line. Dwarf and hybrid F1 D 우 $\times \mathrm{N}{ }^{\top}$ are

744 represented in red whereas normal and hybrid $\mathrm{F} 1 \mathrm{~N}$ 우 $\times \mathrm{D}$ $^{\urcorner}$are represented in green.

745 Figure 6 Metastats results for dwarf, normal and hybrid captive whitefish. Four side-by-side

746 comparisons were performed with dwarf $\left(\mathrm{D}\right.$ 우 $\times \mathrm{D} \varsigma^{\text {\} }) \text {, normal }\left(\mathrm{N} \text { 우 } \times \mathrm{N} \sigma^{\text {}}\right) \text {, hybrid } \mathrm{F} 1 \mathrm{~N} \text { 우 } \times \mathrm{D}$

747 ○ a and hybrid F1 D 우 $\times \mathrm{N} \varsigma^{\top}$. The comparisons are log-transformed and each genus specific to a

748 given whitefish group is represented by a bar plot. Mixed diet and Artemia diet groups are

749 represented by yellow and grey bars, respectively. 
bioRxiv preprint doi: https://doi.org/10.1101/312231; this version posted May 2, 2018. The copyright holder for this preprint (which was not certified by peer review) is the author/funder, who has granted bioRxiv a license to display the preprint in perpetuity. It is made available under aCC-BY-NC-ND 4.0 International license.

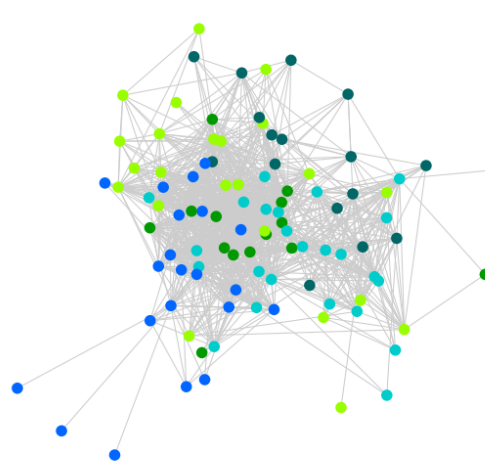

751

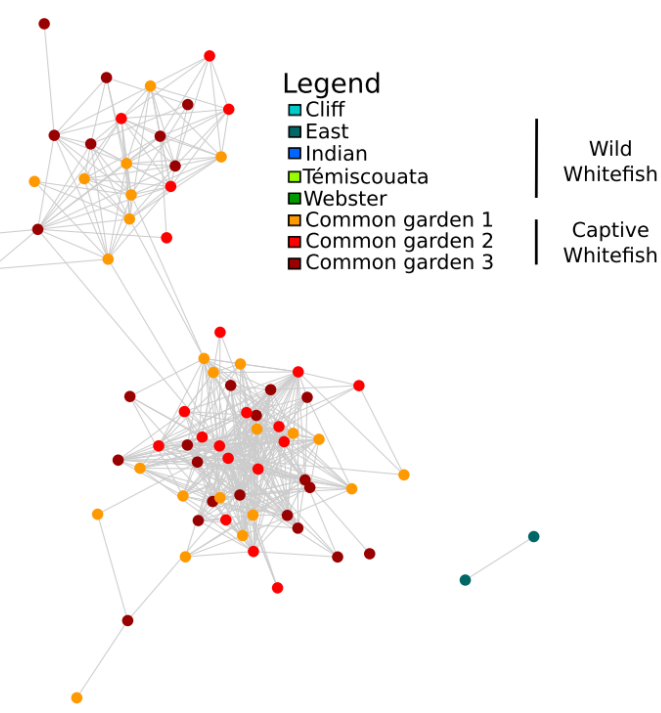




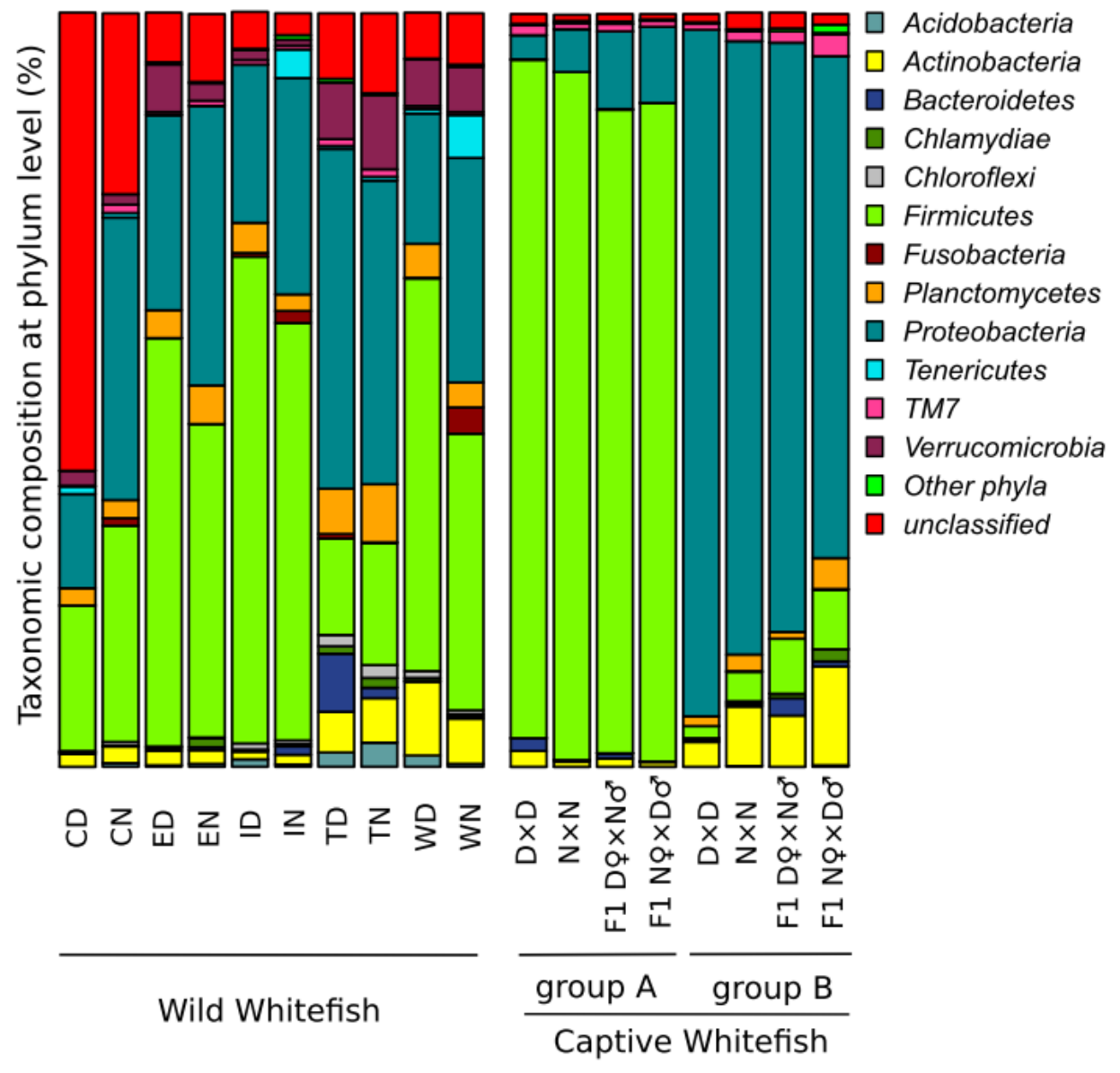


$T$ test, $\mathrm{t}$ value $=-8.127, \mathrm{P}<0.001$

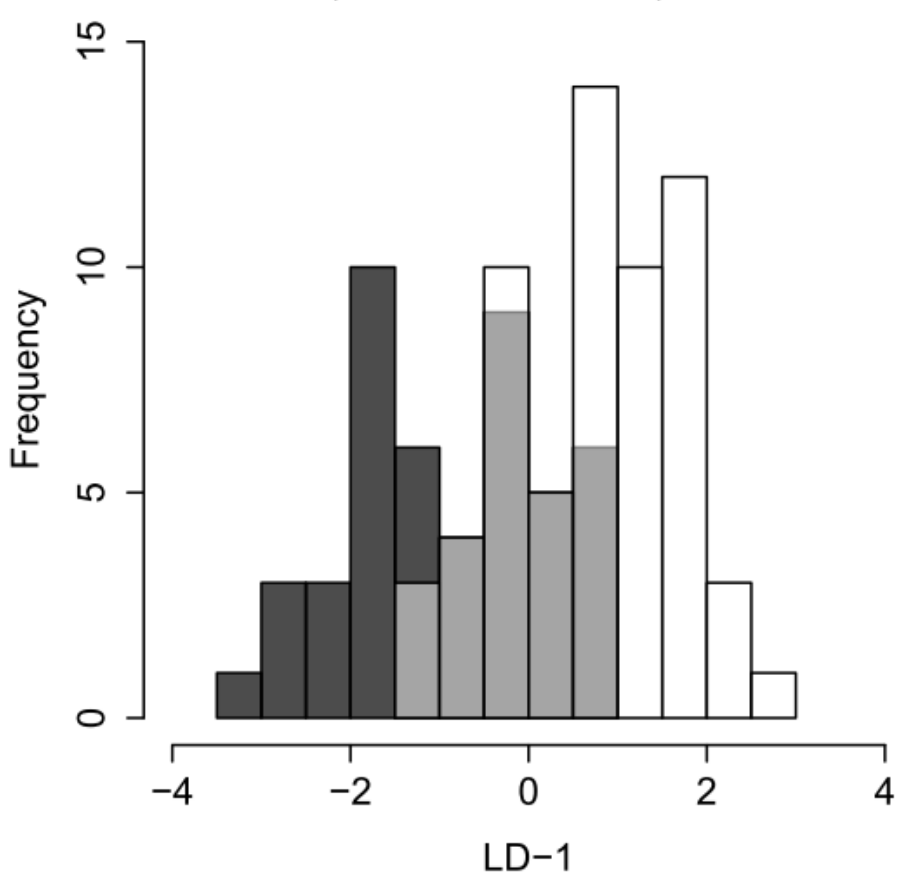


bioRxiv preprint doi: https://doi.org/10.1101/312231; this version posted May 2, 2018. The copyright holder for this preprint (which was not certified by peer review) is the author/funder, who has granted bioRxiv a license to display the preprint in perpetuity. It is made available under aCC-BY-NC-ND 4.0 International license.
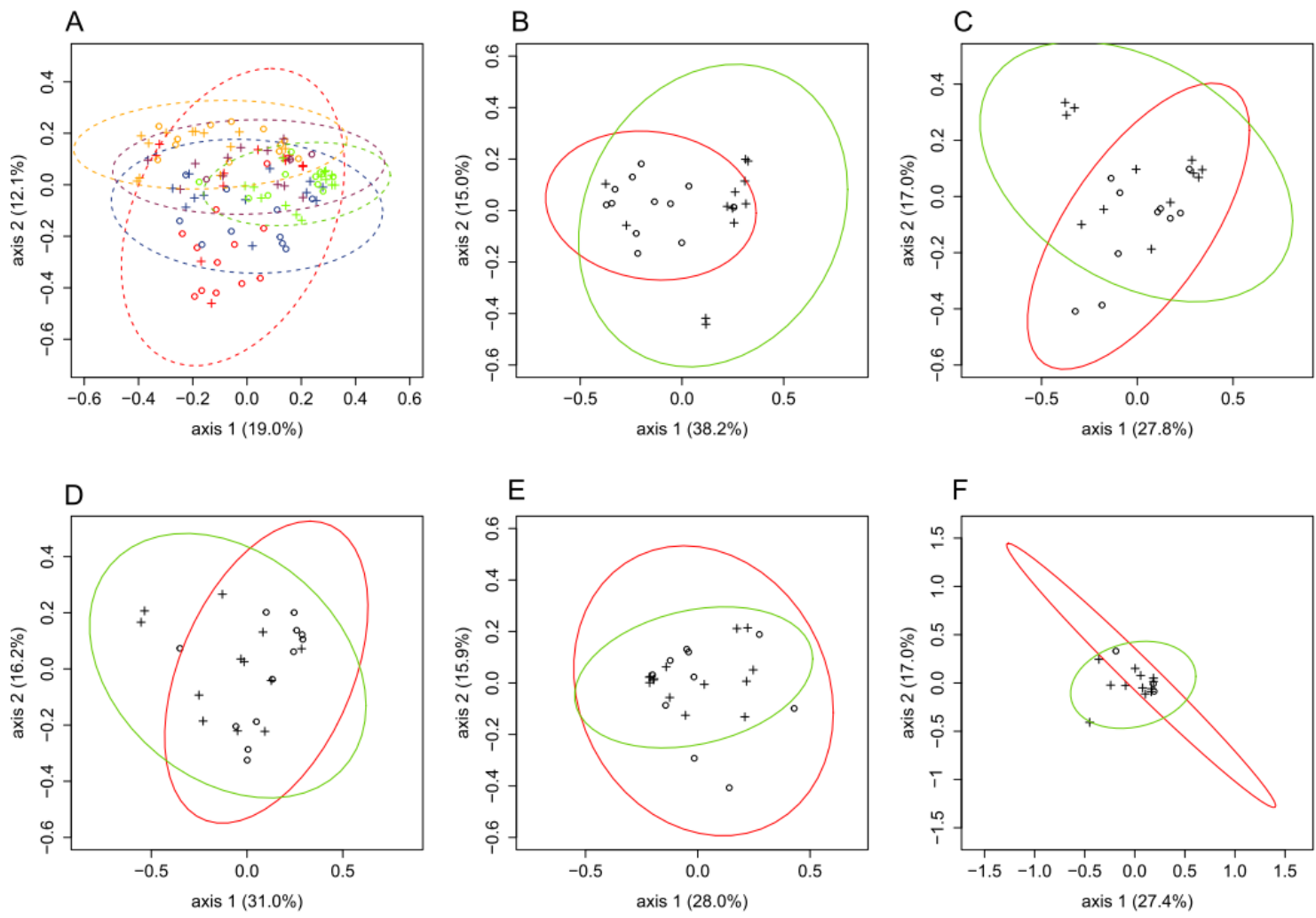
bioRxiv preprint doi: https://doi.org/10.1101/312231; this version posted May 2, 2018. The copyright holder for this preprint (which was not certified by peer review) is the author/funder, who has granted bioRxiv a license to display the preprint in perpetuity. It is made available under aCC-BY-NC-ND 4.0 International license.
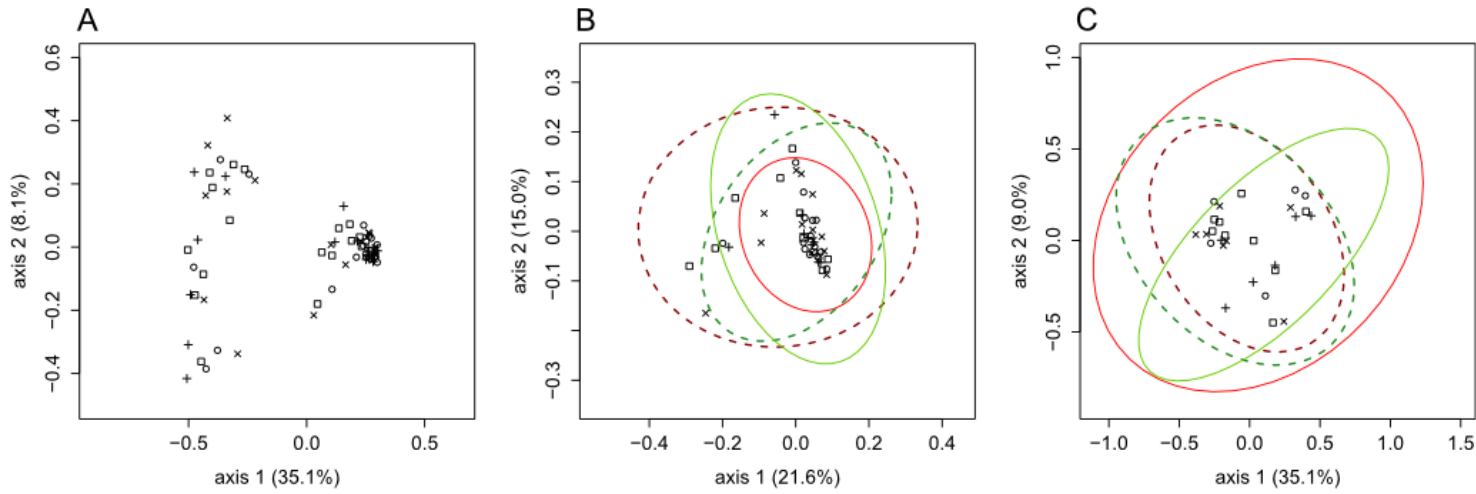

755 
bioRxiv preprint doi: https://doi.org/10.1101/312231; this version posted May 2,2018 . The copyright holder for this preprint (which was not certified by peer review) is the author/funder, who has granted bioRxiv a license to display the preprint in perpetuity. It is made available under aCC-BY-NC-ND 4.0 International license.
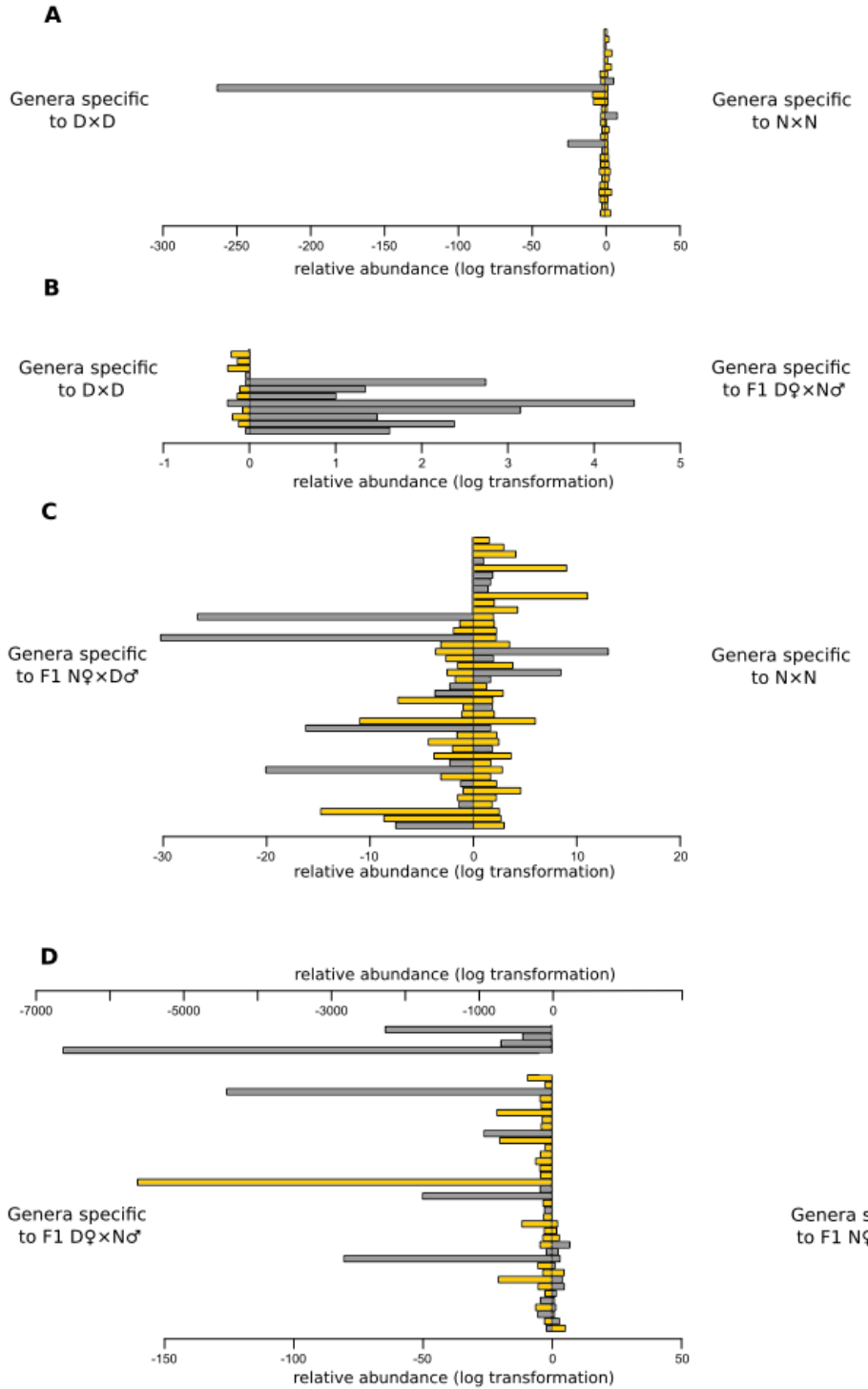

Genera specific to F1 No $\times D^{\circ}$

756 


\section{Supplementary Data}

\section{Experimental crosses of captive whitefish}

758

759

760

761

762

763

764

Whitefish eggs used for this study were incubated at the Laboratoire de Recherche en Sciences Aquatiques (LARSA, Université Laval, Québec, Canada). The dwarf species came from Témiscouata Lake $\left(47^{\circ} 40^{\prime} 04^{\prime} \mathrm{N}, 68^{\circ} 49^{\prime} 03^{\prime \prime} \mathrm{W}\right)$ which is from the Acadian glacial lineage origin whereas the normal species came from Aylmer Lake $\left(45^{\circ} 54^{\prime \prime} \mathrm{N}, 71^{\circ} 20^{\prime \prime} \mathrm{W}\right)$ corresponding to the Atlantic glacial lineage [23]. Backcross F1-Hybrids were obtained by crossing a F1 hybrids laboratory strain and wild whitefish parents. More precisely, $\mathrm{F} 1$ hybrid $(\mathrm{F} 1 \mathrm{D}$ 우 $* \mathrm{~N} \overbrace{}^{\top})$ were produced in crossing three wild dwarf females and two laboratory strain normal males by artificial fertilization. Same processes was used to produced $\mathrm{F} 1$ hybrid $\left(\mathrm{F} 1 \mathrm{~N}\right.$ 우 *D $\left.{ }^{\urcorner}\right)$with crossing five laboratory strain normal females and twelve wild dwarf males (see figure 1 [80]). The dwarf and normal whitefish crosses were also created by artificial fertilization with sperm and eggs were collected in the field and transported to the LARSA. No treatments, such as antibiotics or malachite green were delivered to the eggs.

\section{Whitefish host: DNA extraction, amplification and genetic identification of captive whitefish}

\section{lineages}

A fin clip was collected from all fish and DNA was extracted using a salt extraction method [81] with slight modifications [82]. Mitochondrial (mtDNA) and nuclear DNA were used to identify the whitefish dwarf and normal, and their hybrids (F1 hybrid $\mathrm{D}$ 요 $\mathrm{N}$ and $\mathrm{F} 1$ hybrid $\mathrm{N}$ 우 $\mathrm{D} \overbrace{}^{\urcorner})$. First, an analysis of mtDNA restriction fragment length polymorphism (RFLP) was performed as described in Dalziel et al. since pure dwarf and normal species possess distinct mitochondrial DNA haplotypes $[29,83]$. In brief, after the amplification of the cytochrome b by PCR, the amplified products were digested with SnaBI which cuts the amplified cytochrome $b$ of the normal whitefish haplotype but not of the dwarf. Second, 12 nuclear microsatellite loci were genotyped on all juvenile whitefish and their known parents to differentiate them at the nuclear 
781 DNA level and details about primer sequences and PCR protocols are presented in Rico et al..

782 Three different PCRs were performed for this whitefish microsatellite markers analysis [84].

783 Firstly, the multiplex PCR A was performed with $2 \mu \mathrm{l}(\approx 20 \mathrm{ng})$ of whitefish DNA, $5 \mu \mathrm{L}$ Qiagen ${ }^{\circledR}$

784 multiplex reaction buffer, forward and reverse primers at different concentrations: $0.3 \mu \mathrm{m}$ of

785 Cocl32, Cocl lav41, Cocl Lav8 and $0.35 \mu \mathrm{m}$ of Cocl Lav224; purified water adjusted the final

786 volume at $10 \mu \mathrm{l}$. Multiplex PCR program was: $15 \mathrm{~min}$ at $94^{\circ} \mathrm{C}$, and then 35 cycles of $30 \mathrm{sec}$ at

$78794^{\circ} \mathrm{C}, 3 \mathrm{~min}$ at $58^{\circ} \mathrm{C}, 1 \mathrm{~min}$ at $72^{\circ} \mathrm{C}$ and $30 \mathrm{~min}$ at $60^{\circ} \mathrm{C}$. Secondly, the multiplex PCR B were

788 performed with $2 \mu \mathrm{l}(\approx 20 \mathrm{ng})$ of whitefish DNA, $5 \mu$ L Qiagen ${ }^{\circledR}$ multiplex reaction buffer and

789 forward and reverse primers at different concentration: $6 \mu \mathrm{m}$ of Cocl15 et Cisco200 and $0.25 \mu \mathrm{m}$

790 of Cocl 33; purified water adjusted the final volume at $10 \mu 1$. Multiplex PCR program was: 15

$791 \min$ at $94^{\circ} \mathrm{C}$, and then 35 cycles of $30 \mathrm{sec}$ at $94^{\circ} \mathrm{C}, 3 \mathrm{~min}$ at $60^{\circ} \mathrm{C}, 1 \mathrm{~min}$ at $72^{\circ} \mathrm{C}$ and $30 \mathrm{~min}$ at

$79260^{\circ} \mathrm{C}$. Thirdly, the Simplex PCRs were performed with $2 \mu 1(\approx 20 \mathrm{ng})$ whitefish DNA, $0.2 \mu 1$

793 GoTaq ${ }^{\circledR}$ DNA polymerase (PROMEGA), $0.5 \mu 1$ of each forward and reverse markers $(0.5 \mu \mathrm{m})$

794 (Osmo5, Cocl34, Cocl36, Bwf F-1 and Cocl Lav22) $2 \mu 1$ of 5X Colorless GoTaq ${ }^{\circledR}, 0.6 \mu 1$ of

$795 \mathrm{MgCl} 2(0.5 \mathrm{mM}), 0.8 \mu \mathrm{l} \mathrm{dNTPs}(200 \mu \mathrm{m})$ and purified water adjusted the final volume at $10 \mu \mathrm{l}$.

796 Simplex PCR program was: $2 \mathrm{~min}$ at $94^{\circ} \mathrm{C}$, and then 35 cycles of $30 \mathrm{sec}$ at $94^{\circ} \mathrm{C}, 3 \mathrm{~min}$ at $58^{\circ} \mathrm{C}$

797 (Osmo5, Cocl36, Bwf F-1, Cocl Lav22) or $64^{\circ} \mathrm{C}(\mathrm{Cocl} 34), 1$ min at $72^{\circ} \mathrm{C}$ and 30 min at $60^{\circ} \mathrm{C}$.

798 Amplified loci were migrated via electrophoresis using an ABI 3130xl capillary DNA sequencer

799 (Applied Biosystems Inc.) with a molecular size standard (GeneScan-500 LIZ, Applied

800 Biosystems). Genotypes were scored using Genemapper 4.0 (Applied Biosystems Inc). A

801 combination of three software, STRUCTURE v2.3.4, GENECLASS2 v2.0 and PAPA v2.0 was

802 used to reassign each studied fish to its group of origin [85-87]. STRUCTURE was performed

803 assuming an admixture model without priors with a burn-in period of 50000 followed and

804 100,000 Markov Chain Monte Carlo (MCMC) steps. GENECLASS2 was conducted using the

805 simulation test of [88] based on 100,000 simulated individuals. Finally, PAPA was performed for

806 the parental allocation procedure with a uniform error model (error sum $=0.02)$. 


\section{Supplementary Tables}

Table S1 Steps used to reduce sequencing and PCR errors. We followed the step recommended by MOTHUR in the MiSeq SOP protocol.

\begin{tabular}{|c|c|c|c|}
\hline Main Step of filtration & $\begin{array}{l}\text { Number of } \\
\text { microbiota } \\
\text { wild } \\
\text { whitefish } \\
\text { sequences }\end{array}$ & $\begin{array}{l}\text { Number of } \\
\text { microbiota } \\
\text { captive } \\
\text { whitefish } \\
\text { sequences }\end{array}$ & $\begin{array}{l}\text { Number of } \\
\text { microbiota } \\
\text { captive and } \\
\text { wild } \\
\text { whitefish } \\
\text { sequences }\end{array}$ \\
\hline After contigs construction & 4765128 & 2498271 & 8299965 \\
\hline $\begin{array}{l}\text { Remove sequences with ambiguous bases and } \\
\text { lengths more than } 450 \mathrm{bp}\end{array}$ & 1774729 & 885737 & 2660466 \\
\hline $\begin{array}{l}\text { Aligning paired ends (maximum two mismatches) } \\
\text { and remove sequences with homopolymers of more } \\
\text { than eight bp and with lengths less than } 400 \mathrm{bp}\end{array}$ & 1737037 & 872921 & 2609958 \\
\hline Remove chimeric sequences & 1729598 & 868868 & 2598519 \\
\hline $\begin{array}{l}\text { Remove sequences from chloroplasts, } \\
\text { mitochondria and nonbacterial }\end{array}$ & 1855778 & 845370 & 2498271 \\
\hline Number of final sequences & 1855778 & 845370 & 2498271 \\
\hline Number of OTUs & 94883 & 85363 & 189683 \\
\hline Number of genus & 611 & 433 & 710 \\
\hline Good's Coverage & $95.06 \%$ & $88.22 \%$ & $91.86 \%$ \\
\hline
\end{tabular}

807

808 
Table S2 Matrix of bacterial abundance and Good's coverage per captive whitefish sample. DD: dwarf whitefish, NN: normal whitefish, DH: hybrid F1 D ${ }^{*} \mathrm{No}^{*}, \mathrm{NH}: \mathrm{F} 1 \mathrm{~N}{ }^{*} \mathrm{DO}^{*}$. The diet group A is composed of Artemia and dry food; B is composed of Artemia.

\begin{tabular}{|c|c|c|c|c|c|}
\hline Group & $\begin{array}{l}\text { Whitefish } \\
\text { species }\end{array}$ & $\begin{array}{l}\text { Body mass } \\
\text { (gram) }\end{array}$ & Diet Group & $\begin{array}{l}\text { Number of } \\
\text { sequences }\end{array}$ & $\begin{array}{l}\text { Good's } \\
\text { coverage }\end{array}$ \\
\hline 04-B2F & $\mathrm{NH}$ & 62.50 & A & 9554 & 83.63 \\
\hline 04-B3F & $\mathrm{NH}$ & 68.45 & A & 4047 & 78.95 \\
\hline 05-B1F & $\mathrm{NN}$ & 54.11 & A & 7950 & 87.38 \\
\hline $05-\mathrm{B} 2 \mathrm{~F}$ & DD & 48.75 & A & 4272 & 77.76 \\
\hline 05-B3F & $\mathrm{NH}$ & 49.62 & $\mathrm{~A}$ & 10535 & 84.72 \\
\hline 06-B1F & DH & 20.27 & $\mathrm{~A}$ & 10626 & 86.82 \\
\hline 06-B2F & $\mathrm{NH}$ & 53.55 & A & 9598 & 85.02 \\
\hline 07-B1F & DD & 70.76 & $\mathrm{~A}$ & 10220 & 83.05 \\
\hline 07-B3F & $\mathrm{NN}$ & 66.45 & $\mathrm{~A}$ & 12571 & 88.09 \\
\hline 08-B3F & $\mathrm{NH}$ & 38.24 & A & 4981 & 84.08 \\
\hline 09-B1F & DD & 35.43 & $\mathrm{~A}$ & 8830 & 86.87 \\
\hline 09-B3F & $\mathrm{NN}$ & 78.10 & $\mathrm{~A}$ & 9552 & 78.43 \\
\hline 10-B1F & DD & 66.88 & A & 8965 & 82.96 \\
\hline $10-B 3 F$ & DD & 40.19 & $\mathrm{~A}$ & 5368 & 80.61 \\
\hline 11-B1F & $\mathrm{DD}$ & 70.33 & A & 9494 & 83.98 \\
\hline 11-B3F & DD & 15.23 & A & 4764 & 76.20 \\
\hline 12-B1F & $\mathrm{NH}$ & 41.27 & $\mathrm{~A}$ & 2616 & 81.04 \\
\hline $12-B 2 F$ & DH & 12.24 & A & 11443 & 81.56 \\
\hline 12-B3F & $\mathrm{NH}$ & 96.84 & A & 8438 & 84.55 \\
\hline $13-B 2 F$ & DH & 15.65 & A & 8778 & 84.43 \\
\hline 14-B1F & $\mathrm{NH}$ & 45.23 & A & 7496 & 80.31 \\
\hline 14-B3F & DD & 61.29 & $\mathrm{~A}$ & 8842 & 80.32 \\
\hline 15-B1F & DH & 26.03 & A & 9462 & 86.81 \\
\hline $15-\mathrm{B} 2 \mathrm{~F}$ & NN & 97.68 & A & 9109 & 82.89 \\
\hline $15-B 3 F$ & $\mathrm{DH}$ & 51.04 & A & 7660 & 79.13 \\
\hline $16-\mathrm{B} 3 \mathrm{~F}$ & $\mathrm{NH}$ & 70.71 & A & 7866 & 78.85 \\
\hline 17-B1F & $\mathrm{NN}$ & 64.96 & A & 4621 & 78.84 \\
\hline 17-B3F & DD & 86.65 & A & 7478 & 80.82 \\
\hline $18-\mathrm{B} 2 \mathrm{~F}$ & DD & 78.20 & A & 7387 & 81.18 \\
\hline 19-B3F & $\mathrm{NN}$ & 83.91 & $\mathrm{~A}$ & 14935 & 82.68 \\
\hline 20-B1F & DD & 22.63 & A & 9012 & 80.42 \\
\hline $21-\mathrm{B} 2 \mathrm{~F}$ & NN & 89.88 & A & 9285 & 82.16 \\
\hline 21-B3F & $\mathrm{NN}$ & 49.14 & A & 10663 & 83.77 \\
\hline 22-B1F & $\mathrm{NH}$ & 46.79 & A & 10264 & 85.83 \\
\hline $22-B 2 F$ & DH & 19.08 & A & 14523 & 82.39 \\
\hline 23-B3F & DH & 59.35 & A & 5548 & 81.65 \\
\hline 24-B1F & DH & 19.75 & A & 12012 & 83.70 \\
\hline 24-B2F & DD & 62.52 & A & 3249 & 75.62 \\
\hline
\end{tabular}




\begin{tabular}{|c|c|c|c|c|c|}
\hline 24-B3F & $\mathrm{DD}$ & 3.60 & A & 7171 & 80.83 \\
\hline 25-B1F & $\mathrm{NH}$ & 63.67 & A & 10637 & 81.66 \\
\hline 26-B2F & NN & 32.98 & A & 7388 & 83.05 \\
\hline 27-B2F & $\mathrm{NH}$ & 57.57 & A & 11992 & 91.12 \\
\hline 27-B3F & $\mathrm{DD}$ & 45.78 & A & 12970 & 88.66 \\
\hline 29-B1F & $\mathrm{NH}$ & 55.69 & A & 16608 & 84.97 \\
\hline $30-\mathrm{B} 2 \mathrm{~F}$ & DD & 41.33 & A & 8130 & 83.89 \\
\hline $33-B 2 F$ & DH & 2.99 & A & 7908 & 90.59 \\
\hline 33-B3F & DH & 28.31 & A & 7948 & 81.35 \\
\hline 02-B1F & $\mathrm{NH}$ & 58.59 & B & 7773 & 96.57 \\
\hline 03-B3F & $\mathrm{NH}$ & 64.97 & B & 14847 & 99.51 \\
\hline 06-B3F & DH & 3.59 & B & 9042 & 98.83 \\
\hline 07-B2F & DD & 2.82 & B & 3941 & 97.64 \\
\hline 08-B1F & DD & 6.08 & B & 16447 & 98.61 \\
\hline 08-B2F & $\mathrm{NH}$ & 3.44 & B & 12825 & 99.27 \\
\hline 09-B2F & $\mathrm{NH}$ & 5.80 & B & 24288 & 96.83 \\
\hline $10-\mathrm{B} 2 \mathrm{~F}$ & DH & 3.55 & B & 20371 & 99.36 \\
\hline 13-B1F & DH & 2.93 & B & 7346 & 94.80 \\
\hline 16-B1F & DH & 6.29 & B & 13921 & 98.99 \\
\hline 18-B1F & DH & 1.57 & B & 10261 & 94.29 \\
\hline 19-B2F & NN & 3.09 & B & 16329 & 98.51 \\
\hline $20-B 2 F$ & $\mathrm{NH}$ & 57.16 & B & 13028 & 98.53 \\
\hline 20-B3F & $\mathrm{NH}$ & 7.57 & B & 14615 & 98.47 \\
\hline 21-B1F & $\mathrm{NN}$ & 2.85 & B & 6503 & 97.91 \\
\hline 22-B3F & DD & 3.01 & B & 9433 & 99.14 \\
\hline 23-B1F & DH & 2.41 & B & 11224 & 97.46 \\
\hline $25-B 2 F$ & DH & 2.65 & B & 19484 & 99.12 \\
\hline $25-\mathrm{B} 3 \mathrm{~F}$ & DD & 70.32 & B & 15942 & 99.43 \\
\hline 26-B1F & $\mathrm{NN}$ & 2.85 & B & 11586 & 99.07 \\
\hline 26-B3F & NN & 3.55 & B & 14829 & 98.92 \\
\hline 28-B3F & NN & 3.71 & B & 17491 & 99.40 \\
\hline 29-B3F & DH & 2.71 & B & 7009 & 97.73 \\
\hline 30-B3F & DH & 3.12 & B & 28573 & 99.30 \\
\hline 31-B1F & DD & 7.26 & B & 17016 & 96.21 \\
\hline 31-B3F & $\mathrm{NH}$ & 2.50 & B & 12031 & 99.13 \\
\hline 32-B1F & NN & 4.77 & $\mathrm{~B}$ & 13956 & 98.64 \\
\hline
\end{tabular}

809

810 
811 Table S3 Summary of ANOVA test statistics on microbiota alpha diversity (inverse Simpson 812 index). All lakes refer to the analysis of effect of host species (dwarf and normal), lake (Cliff,

813 East, Indian, Témiscouata and Webster). Second, the effect of host species is treated for each lake

814 separately. Third, CAPTIVE refers to the analysis of effect of host group (dwarf, normal, hybrids

815 D 우 $\mathrm{N}^{\top}$ and $\mathrm{N}$ 우 $\mathrm{D}^{\top}$ ), diet (Artemia only and Artemia with dry food) on all captive fish. Fourth,

816 effect of captivity (wild and captive), dwarf only and normal only. F-Value is the value of the F

817 statistic.

818

\begin{tabular}{lllll}
\hline Fish group & Source of variation & $\begin{array}{l}\text { Degrees of } \\
\text { freedom }\end{array}$ & F value & P value \\
\hline WILD & Species & 1 & 0.439 & 0.510 \\
All lakes & Lakes & 4 & 2.304 & 0.064 \\
& Lakes:Species & 4 & 1.152 & 0.337 \\
Cliff & Species & 1 & 0.109 & 0.744 \\
Est & Species & 1 & 0.025 & 0.876 \\
Indian & Species & 1 & 2.026 & 0.169 \\
Témiscouata & Species & 1 & 1.557 & 0.225 \\
Webster & Species & 1 & 0.824 & 0.380 \\
CAPTIVE & & & & \\
& Group & 3 & 0.599 & 0.620 \\
& Diet & 1 & 40.471 & 0.001 \\
BoTH & Species:Diet & 3 & 1.930 & 0.134 \\
All fish & & & & 0.157 \\
Dwarf & Captivity & 1 & 2.044 & 0.003 \\
\hline & Captivity & 1 & 2.040 & 0.157 \\
\hline
\end{tabular}


820 Table S4: Four Metastats tables with details of one-species-specific genera. DD: dwarf whitefish,

821 NN: normal whitefish, DH: hybrid F1 D $*^{*}$ No", NH: F1 NO*Do*. The diet group A is composed

822 of Artemia and dry food; B is composed of Artemia.

\begin{tabular}{lll}
\hline $\begin{array}{l}\text { Metastats comparison } \\
\text { whitefish }\end{array}$ & DD and DH captive \\
Genera & Diet group & Groups \\
\hline Aquicella & $\mathrm{B}$ & $\mathrm{DD}$ \\
Flavobacterium & $\mathrm{B}$ & $\mathrm{DD}$ \\
Fusobacterium & $\mathrm{B}$ & $\mathrm{DD}$ \\
Lactobacillus & $\mathrm{B}$ & $\mathrm{DD}$ \\
Leuconostoc & $\mathrm{B}$ & $\mathrm{DD}$ \\
Sphingobium & $\mathrm{B}$ & $\mathrm{DD}$ \\
Streptococcus & $\mathrm{B}$ & $\mathrm{DD}$ \\
Weissella & $\mathrm{B}$ & $\mathrm{DD}$ \\
Aeromonas & $\mathrm{A}$ & $\mathrm{DD}$ \\
Kocuria & $\mathrm{A}$ & $\mathrm{DD}$ \\
Nocardioides & $\mathrm{A}$ & $\mathrm{DD}$ \\
Rhodobacter & $\mathrm{A}$ & $\mathrm{DD}$ \\
Corynebacterium & $\mathrm{A}$ & $\mathrm{DH}$ \\
Delftia & $\mathrm{A}$ & $\mathrm{DH}$ \\
Labrenzia & $\mathrm{A}$ & $\mathrm{DH}$ \\
Legionella & $\mathrm{A}$ & $\mathrm{DH}$ \\
Paracoccus & $\mathrm{A}$ & $\mathrm{DH}$ \\
Planctomyces & $\mathrm{A}$ & $\mathrm{DH}$ \\
Pseudomonas & $\mathrm{A}$ & $\mathrm{DH}$ \\
Stenotrophomonas & $\mathrm{A}$ & $\mathrm{DH}$ \\
\hline
\end{tabular}

Metastats comparison NN and NH captive whitefish

\begin{tabular}{lll} 
Genera & Diet group & Groups \\
\hline Acinetobacter & $\mathrm{B}$ & $\mathrm{NH}$ \\
Aerococcus & $\mathrm{B}$ & $\mathrm{NH}$ \\
Brachymonas & $\mathrm{B}$ & $\mathrm{NH}$ \\
Brevibacterium & $\mathrm{B}$ & $\mathrm{NH}$ \\
Catonella & $\mathrm{B}$ & $\mathrm{NH}$ \\
Cupriavidus & $\mathrm{B}$ & $\mathrm{NH}$ \\
Dermacoccus & $\mathrm{B}$ & $\mathrm{NH}$ \\
Escherichia_Shigella & $\mathrm{B}$ & $\mathrm{NH}$ \\
Kocuria & $\mathrm{B}$ & $\mathrm{NH}$ \\
Leptotrichia & $\mathrm{B}$ & $\mathrm{NH}$ \\
Mycobacterium & $\mathrm{B}$ & $\mathrm{NH}$
\end{tabular}




\begin{tabular}{|c|c|c|}
\hline Neisseria & B & $\mathrm{NH}$ \\
\hline Oceanobacillus & B & $\mathrm{NH}$ \\
\hline Paenibacillus & B & $\mathrm{NH}$ \\
\hline Pediococcus & B & $\mathrm{NH}$ \\
\hline Peptococcus & B & $\mathrm{NH}$ \\
\hline Rhizobium & B & $\mathrm{NH}$ \\
\hline Roseomonas & B & $\mathrm{NH}$ \\
\hline Sphingobacterium & B & $\mathrm{NH}$ \\
\hline Turneriella & B & $\mathrm{NH}$ \\
\hline Vibrio & B & $\mathrm{NH}$ \\
\hline Acinetobacter & A & $\mathrm{NH}$ \\
\hline Bifidobacterium & A & $\mathrm{NH}$ \\
\hline Brevundimonas & A & $\mathrm{NH}$ \\
\hline Chryseobacterium & $\mathrm{A}$ & $\mathrm{NH}$ \\
\hline Collimonas & $\mathrm{A}$ & $\mathrm{NH}$ \\
\hline Lactobacillus & A & $\mathrm{NH}$ \\
\hline Ohtaekwangia & $\mathrm{A}$ & $\mathrm{NH}$ \\
\hline Olsenella & $\mathrm{A}$ & $\mathrm{NH}$ \\
\hline Streptococcus & A & $\mathrm{NH}$ \\
\hline Weissella & $\mathrm{A}$ & $\mathrm{NH}$ \\
\hline Acetobacterium & $\mathrm{B}$ & $\mathrm{NN}$ \\
\hline Acidovorax & $\mathrm{B}$ & $\mathrm{NN}$ \\
\hline Aeriscardovia & B & $\mathrm{NN}$ \\
\hline Aneurinibacillus & $\mathrm{B}$ & $\mathrm{NN}$ \\
\hline Aquabacterium & $\mathrm{B}$ & $\mathrm{NN}$ \\
\hline Arcobacter & $\mathrm{B}$ & $\mathrm{NN}$ \\
\hline Arthrobacter & B & $\mathrm{NN}$ \\
\hline Bacillus & $\mathrm{B}$ & $\mathrm{NN}$ \\
\hline Bifidobacterium & B & $\mathrm{NN}$ \\
\hline Brevibacillus & $\mathrm{B}$ & $\mathrm{NN}$ \\
\hline Cellvibrio & B & $\mathrm{NN}$ \\
\hline Devosia & B & $\mathrm{NN}$ \\
\hline Duganella & B & $\mathrm{NN}$ \\
\hline Enhydrobacter & B & $\mathrm{NN}$ \\
\hline Ethanoligenens & B & $\mathrm{NN}$ \\
\hline Gemella & B & $\mathrm{NN}$ \\
\hline Haemophilus & B & $\mathrm{NN}$ \\
\hline Hyphomicrobium & B & $\mathrm{NN}$ \\
\hline Legionella & B & NN \\
\hline Massilia & B & $\mathrm{NN}$ \\
\hline Megasphaera & B & $\mathrm{NN}$ \\
\hline Methyloversatilis & B & $\mathrm{NN}$ \\
\hline Novosphingobium & B & NN \\
\hline
\end{tabular}




\begin{tabular}{lll} 
Prauserella & B & NN \\
Pseudomonas & B & NN \\
Psychrilyobacter & B & NN \\
Rothia & B & NN \\
Sphaerobacter & B & NN \\
Sphingobium & $\mathrm{B}$ & $\mathrm{NN}$ \\
Sphingomonas & $\mathrm{B}$ & $\mathrm{NN}$ \\
Undibacterium & $\mathrm{B}$ & $\mathrm{NN}$ \\
Comamonas & $\mathrm{A}$ & $\mathrm{NN}$ \\
Elizabethkingia & $\mathrm{A}$ & $\mathrm{NN}$ \\
Flavobacterium & $\mathrm{A}$ & $\mathrm{NN}$ \\
Ilumatobacter & $\mathrm{A}$ & $\mathrm{NN}$ \\
Labrenzia & $\mathrm{A}$ & $\mathrm{NN}$ \\
Leuconostoc & $\mathrm{A}$ & $\mathrm{NN}$ \\
Listonella & $\mathrm{A}$ & $\mathrm{NN}$ \\
Psychrobacter & $\mathrm{A}$ & $\mathrm{NN}$ \\
Rhizobium & $\mathrm{A}$ & $\mathrm{NN}$ \\
Rhodopirellula & $\mathrm{A}$ & $\mathrm{NN}$ \\
Shewanella & $\mathrm{A}$ & $\mathrm{NN}$ \\
\hline
\end{tabular}

824

Metastats comparison $\mathrm{NH}$ and DH captive whitefish

\begin{tabular}{lll} 
Genera & Diet group & Groups \\
\hline Aliivibrio & $\mathrm{B}$ & $\mathrm{DH}$ \\
Aneurinibacillus & $\mathrm{B}$ & $\mathrm{DH}$ \\
Arcobacter & $\mathrm{B}$ & $\mathrm{DH}$ \\
Clostridium_sensu_stricto & $\mathrm{B}$ & $\mathrm{DH}$ \\
Clostridium_XI & $\mathrm{B}$ & $\mathrm{DH}$ \\
Comamonas & $\mathrm{B}$ & $\mathrm{DH}$ \\
Deinococcus & $\mathrm{B}$ & $\mathrm{DH}$ \\
Dickeya & $\mathrm{B}$ & $\mathrm{DH}$ \\
Dokdonella & $\mathrm{B}$ & $\mathrm{DH}$ \\
Elizabethkingia & $\mathrm{B}$ & $\mathrm{DH}$ \\
Enhydrobacter & $\mathrm{B}$ & $\mathrm{DH}$ \\
Exiguobacterium & $\mathrm{B}$ & $\mathrm{DH}$ \\
Gemella & $\mathrm{B}$ & $\mathrm{DH}$ \\
Legionella & $\mathrm{B}$ & $\mathrm{DH}$ \\
Limnohabitans & $\mathrm{B}$ & $\mathrm{DH}$ \\
Megasphaera & $\mathrm{B}$ & $\mathrm{DH}$ \\
Novosphingobium & $\mathrm{B}$ & $\mathrm{DH}$ \\
Phenylobacterium & $\mathrm{B}$ & $\mathrm{DH}$ \\
Proteiniclasticum & $\mathrm{B}$ & $\mathrm{DH}$
\end{tabular}




\begin{tabular}{|c|c|c|}
\hline Pseudomonas & B & $\mathrm{DH}$ \\
\hline Rhodobacter & $\mathrm{B}$ & DH \\
\hline Salinimicrobium & $\mathrm{B}$ & DH \\
\hline Shewanella & B & DH \\
\hline Sphingobacterium & $\mathrm{B}$ & DH \\
\hline Sphingobium & B & DH \\
\hline Thermomonas & $\mathrm{B}$ & DH \\
\hline Wautersiella & B & DH \\
\hline Aerococcus & $\mathrm{A}$ & DH \\
\hline Alkanindiges & A & DH \\
\hline Aquabacterium & A & DH \\
\hline Delftia & A & DH \\
\hline Desulfovibrio & A & DH \\
\hline Flavobacterium & A & DH \\
\hline Labrenzia & A & DH \\
\hline Legionella & A & DH \\
\hline Psychrobacter & A & DH \\
\hline Stenotrophomonas & A & DH \\
\hline Listonella & A & DH \\
\hline Trichococcus & A & DH \\
\hline Methylobacterium & A & DH \\
\hline Paracoccus & A & DH \\
\hline Aerococcus & B & $\mathrm{NH}$ \\
\hline Leptotrichia & $\mathrm{B}$ & $\mathrm{NH}$ \\
\hline Pediococcus & B & $\mathrm{NH}$ \\
\hline Photobacterium & $\mathrm{B}$ & $\mathrm{NH}$ \\
\hline Turneriella & B & $\mathrm{NH}$ \\
\hline Aquitalea & A & $\mathrm{NH}$ \\
\hline Bifidobacterium & A & NH \\
\hline Brevundimonas & A & $\mathrm{NH}$ \\
\hline Devosia & A & NH \\
\hline Gemmata & $\mathrm{A}$ & NH \\
\hline Hyphomicrobium & A & NH \\
\hline Lactobacillus & $\mathrm{A}$ & NH \\
\hline Oerskovia & A & NH \\
\hline Ohtaekwangia & A & $\mathrm{NH}$ \\
\hline Olsenella & A & NH \\
\hline Pasteuria & A & $\mathrm{NH}$ \\
\hline
\end{tabular}


Metastats comparison NN and DD captive whitefish

\begin{tabular}{|c|c|c|}
\hline Genera & Diet group & Groups \\
\hline Acinetobacter & $\mathrm{B}$ & DD \\
\hline Actinomyces & $\mathrm{B}$ & DD \\
\hline Anoxybacillus & $\mathrm{B}$ & DD \\
\hline Aquicella & $\mathrm{B}$ & DD \\
\hline Barnesiella & $\mathrm{B}$ & DD \\
\hline Brevundimonas & $\mathrm{B}$ & DD \\
\hline Campylobacter & $\mathrm{B}$ & $\mathrm{DD}$ \\
\hline Cerasibacillus & $\mathrm{B}$ & DD \\
\hline Faecalibacterium & $\mathrm{B}$ & DD \\
\hline Oceanobacillus & $\mathrm{B}$ & DD \\
\hline Ohtaekwangia & $\mathrm{B}$ & DD \\
\hline Prevotella & $\mathrm{B}$ & DD \\
\hline Pseudolabrys & $\mathrm{B}$ & DD \\
\hline Rhodococcus & $\mathrm{B}$ & $\mathrm{DD}$ \\
\hline Sphingobium & $\mathrm{B}$ & DD \\
\hline Sphingomonas & $\mathrm{B}$ & DD \\
\hline Thermoflavimicrobium & $\mathrm{B}$ & DD \\
\hline Vogesella & $\mathrm{B}$ & DD \\
\hline Gp6 & $\mathrm{A}$ & DD \\
\hline Lactobacillus & $\mathrm{A}$ & DD \\
\hline Streptococcus & $\mathrm{A}$ & DD \\
\hline Alishewanella & $\mathrm{B}$ & $\mathrm{NN}$ \\
\hline Aneurinibacillus & $\mathrm{B}$ & NN \\
\hline Aquabacterium & $\mathrm{B}$ & $\mathrm{NN}$ \\
\hline Arcobacter & $\mathrm{B}$ & $\mathrm{NN}$ \\
\hline Arthrobacter & B & NN \\
\hline Bifidobacterium & B & NN \\
\hline Cellvibrio & $\mathrm{B}$ & $\mathrm{NN}$ \\
\hline Corynebacterium & $\mathrm{B}$ & $\mathrm{NN}$ \\
\hline Devosia & B & NN \\
\hline Duganella & B & NN \\
\hline Ethanoligenens & $\mathrm{B}$ & $\mathrm{NN}$ \\
\hline Gemella & $\mathrm{B}$ & $\mathrm{NN}$ \\
\hline Haemophilus & B & NN \\
\hline Hyphomicrobium & B & NN \\
\hline Megasphaera & $\mathrm{B}$ & $\mathrm{NN}$ \\
\hline Methyloversatilis & $\mathrm{B}$ & $\mathrm{NN}$ \\
\hline Novosphingobium & B & NN \\
\hline Photobacterium & $\mathrm{B}$ & $\mathrm{NN}$ \\
\hline Prauserella & $\mathrm{B}$ & $\mathrm{NN}$ \\
\hline
\end{tabular}


bioRxiv preprint doi: https://doi.org/10.1101/312231; this version posted May 2, 2018. The copyright holder for this preprint (which was not certified by peer review) is the author/funder, who has granted bioRxiv a license to display the preprint in perpetuity. It is made available under aCC-BY-NC-ND 4.0 International license.

\section{7}

\begin{tabular}{lll} 
Pseudomonas & $\mathrm{B}$ & $\mathrm{NN}$ \\
Rothia & $\mathrm{B}$ & $\mathrm{NN}$ \\
Shewanella & $\mathrm{B}$ & $\mathrm{NN}$ \\
Sphaerobacter & $\mathrm{B}$ & $\mathrm{NN}$ \\
Tissierella & $\mathrm{B}$ & $\mathrm{NN}$ \\
Undibacterium & $\mathrm{B}$ & $\mathrm{NN}$ \\
Labrenzia & $\mathrm{A}$ & $\mathrm{NN}$ \\
Planctomyces & $\mathrm{A}$ & $\mathrm{NN}$ \\
\hline
\end{tabular}

828 


\section{Supplementary Figures}

829 Figure S1 Network analysis of intestinal microbiota of dwarf and normal wild whitefish and

830 intestinal microbiota of dwarf, normal and hybrids captive whitefish. The nodes represent a dwarf

831 or a normal or a hybrid whitefish microbiota. More precisely, DD: dwarf whitefish, NN: normal

832 whitefish, DH: hybrid F1 DQ*No", NH: F1 NO*Do*. The connecting lines between two samples

833 represent their correlation and is highlighting by a Spearman index. 
bioRxiv preprint doi: https://doi.org/10.1101/312231; this version posted May 2, 2018. The copyright holder for this preprint (which was not certified by peer review) is the author/funder, who has granted bioRxiv a license to display the preprint in perpetuity. It is made available under aCC-BY-NC-ND 4.0 International license.

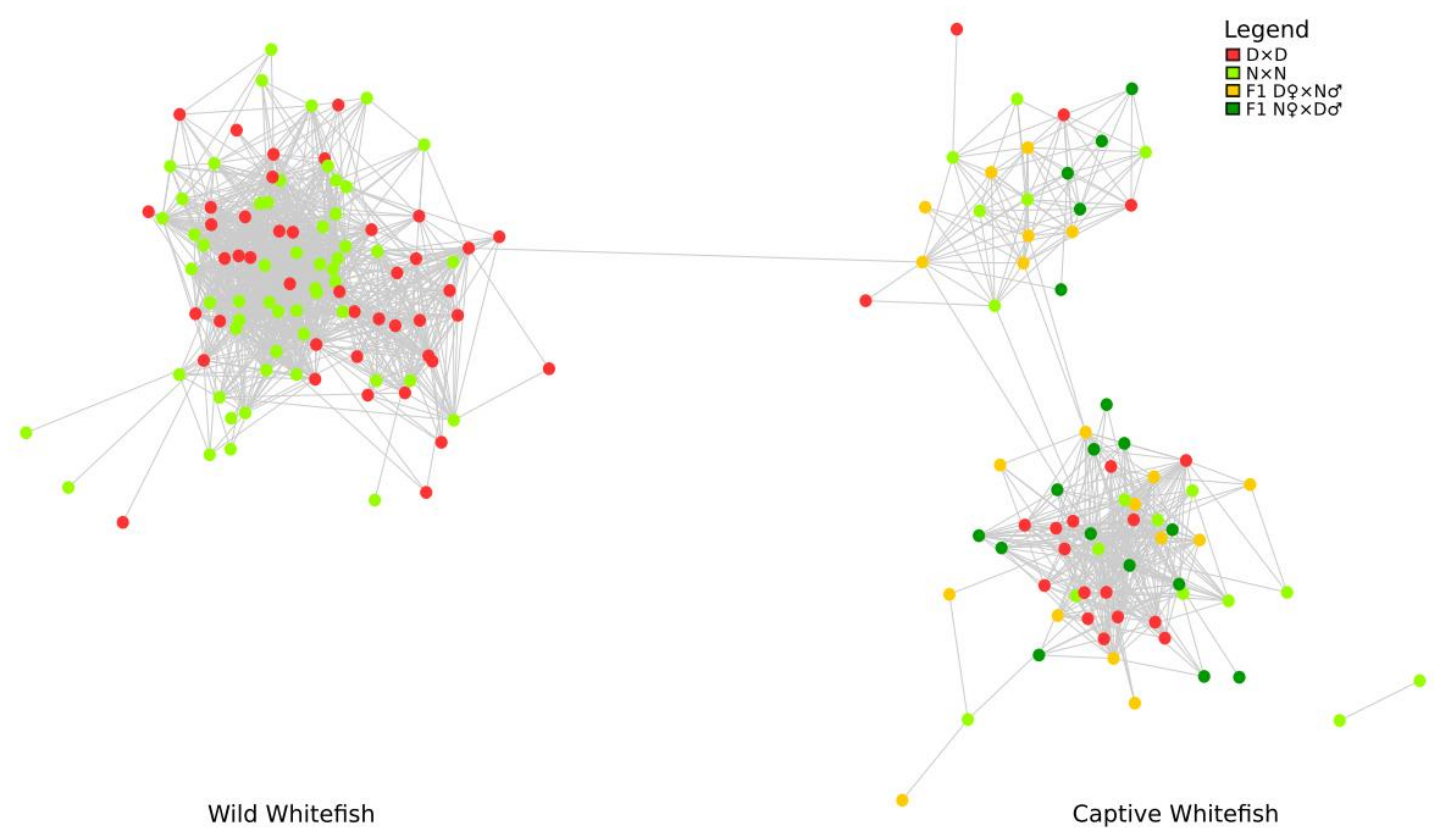

834 